\title{
Transcriptomic-based clustering of advanced atherosclerotic plaques identifies subgroups of plaques with differential underlying biology that associate with
}

\section{clinical presentation.}

Michal Mokry ${ }^{1,2}$, Arjan Boltjes ${ }^{1}$, Kai Cui ${ }^{2}$, Lotte Slenders ${ }^{1}$, Joost M. Mekke ${ }^{3}$, Marie A.C. Depuydt ${ }^{4}$, Nathalie Timmerman ${ }^{3}$, Farahnaz Waissi ${ }^{3}$, Maarten C Verwer ${ }^{3}$, Adam W. Turner ${ }^{5}$, Mohammad Daud Khan ${ }^{5}$, Chani J. Hodonsky ${ }^{5}$, Ernest Diez Benavente ${ }^{2}$, Robin J.G. Hartman ${ }^{2}$, Noortje A M van den Dungen ${ }^{1}$, Nico Lansu ${ }^{1}$, Emilia Nagyova ${ }^{1}$, Koen H.M. Prange ${ }^{6}$, Eleftherios Pavlos ${ }^{7}$, Evangelos Andreakos ${ }^{7}$, Heribert Schunkert ${ }^{8,9}$, Gary K. Owens ${ }^{10,11}$, Claudia Monaco ${ }^{12}$, Aloke V Finn ${ }^{13}$, Renu Virmani ${ }^{13}$, Nicholas J. Leeper ${ }^{14}$, Menno P.J. de Winther $^{6}$, Johan Kuiper ${ }^{4}$, Gert J. de Borst ${ }^{3}$, Erik S.G. Stroes ${ }^{15}$, Mete Civelek ${ }^{16,17}$, Dominique P.V. de Kleijn ${ }^{3}$, Hester M. den Ruijter ${ }^{2}$, Folkert W. Asselbergs ${ }^{2}$, Sander W. van der Laan ${ }^{1}$, Clint L. Miller ${ }^{5,16,17 \#, ~ G e r a r d ~}$ Pasterkamp ${ }^{1 \#^{*}}$

\section{Affiliations}

1. Central Diagnostics Laboratory, University Medical Center Utrecht, University Utrecht, Utrecht, The Netherlands.

2. Laboratory of Experimental Cardiology, Department of Cardiology, University Medical Center Utrecht, University Utrecht, Utrecht, The Netherlands

3. Department of Vascular Surgery, University Medical Centre Utrecht, Utrecht, The Netherlands

4. Leiden Academic Centre for Drug Research, Division of Biotherapeutics, Leiden University, Leiden, The Netherlands

5. Department of Public Health Sciences, University of Virginia, Charlottesville, VA, USA

6. Amsterdam University Medical Centers - location AMC, University of Amsterdam, Experimental Vascular Biology, Department of Medical Biochemistry, Amsterdam Cardiovascular Sciences, Amsterdam, The Netherlands 
medRxiv preprint doi: https://doi.org/10.1101/2021.11.25.21266855; this version posted November 26, 2021. The copyright holder for this preprint (which was not certified by peer review) is the author/funder, who has granted medRxiv a license to display the preprint in perpetuity. It is made available under a CC-BY-NC-ND 4.0 International license .

7. Laboratory of Immunobiology, Center for Clinical, Experimental Surgery and Translational Research, Biomedical Research Foundation of the Academy of Athens, Athens, Greece

8. Department of Cardiology, German Heart Centre Munich, Technical University of Munich, Munich, Germany.

9. German Centre for Cardiovascular Research (DZHK e.V.), Partner Site Munich Heart Alliance, Munich, Germany.

10. Robert M. Berne Cardiovascular Research Center, University of Virginia, Charlottesville, VA, USA

11. Department of Molecular Physiology and Biological Physics, University of Virginia, Charlottesville, VA, USA

12. Kennedy Institute of Rheumatology, Nuffield Department of Orthopaedics, Rheumatology and Musculoskeletal Sciences, University of Oxford, Oxford, UK

13. CVPath Institute, Inc, Gaithersburg, MD, USA

14. Department of Surgery, Division of Vascular Surgery, Stanford University School of Medicine, Stanford, CA

15. Department of Vascular Medicine, Amsterdam University Medical Centers, Location AMC, Amsterdam, the Netherlands.

16. Department of Biomedical Engineering, Center for Public Health Genomics, University of Virginia, Charlottesville, VA, USA

17. Department of Biochemistry and Molecular Genetics, University of Virginia, Charlottesville, VA, USA

\# joint last authorship

*Correspondence

Gerard Pasterkamp, MD PhD

Central Diagnostics Laboratory, University Medical Center Utrecht

Heidelberglaan 100

3584 CX Utrecht, the Netherlands

Email: g.pasterkamp@umcutrecht.nl 


\section{Abstract}

Histopathological studies have revealed key processes of atherosclerotic plaque thrombosis. However, the diversity and complexity of lesion types highlight the need for improved subphenotyping. We hypothesized that unbiased clustering of plaques based on gene expression results in an alternative categorization of late-stage atherosclerotic lesions.

We analyzed the gene expression profiles of 654 advanced human carotid plaques. The unsupervised, transcriptome-driven clustering revealed five dominant plaque types. These novel plaque phenotypes associated with clinical presentation $(p<0.001)$ and showed differences in cellular compositions. Validation in coronary segments showed that the molecular signature of these plaques was linked to coronary ischemia. One of the plaque types with most severe clinical symptoms pointed to both inflammatory and fibrotic cell lineages. This highlighted plaque phenotype showed high expression of genes involved in active inflammatory processes, neutrophil degranulation, matrix turnover, and metabolism. For clinical translation, we did a first promising attempt to identify circulating biomarkers that mark these newly identified plaque phenotypes.

In conclusion, the definition of the plaque at risk for a thrombotic event can be fine-tuned by indepth transcriptomic based phenotyping. These differential plaque phenotypes prove clinically relevant for both carotid and coronary artery plaques and point to differential underlying biology of symptomatic lesions. 
medRxiv preprint doi: https://doi.org/10.1101/2021.11.25.21266855; this version posted November 26, 2021. The copyright holder for this preprint (which was not certified by peer review) is the author/funder, who has granted medRxiv a license to display the preprint in perpetuity.

It is made available under a CC-BY-NC-ND 4.0 International license .

\section{Introduction}

The classical concept of the 'vulnerable plaque' that depicts the plaque rupture as the major pathological substrate for acute cardiovascular events originated in the 1980s from observations in patients who died of coronary syndromes ${ }^{1,2}$. This recognition spawned a generation of research that led to a greater understanding of how complicated atherosclerotic plaques form and precipitate into thromboembolic events secondary to plaque rupture. Current evidence suggests that a sole focus on plaque rupture of atheromatous lesions in clinical and basic research may have oversimplified the complex collection of atherosclerotic diseases and obscured other mechanisms that may mandate different management strategies.

In addition to histology, molecular phenotyping using the whole transcriptome provides more resolution and allows an in-depth understanding and discovery of processes active in the diseased vascular tissue ${ }^{3-}$ ${ }^{6}$. These studies successfully utilized the gene co-expression networks or compared cases and controls. However, they did not attempt to redefine the plaque type definitions based on gene expression signatures. Unsupervised cluster analysis, based on transcriptomic datasets, can be used to group patients with similar molecular characteristics of the diseased tissue and have the potential to unravel disease phenotypes that fine-tunes the patho-histological evaluation ${ }^{7-10}$. This approach is often used in cancer research and led to the identification of novel tumor subtypes. We, therefore hypothesized that unbiased clustering based on gene expression of human advanced atherosclerotic plaques unveils novel phenotypes of late-stage human atherosclerotic plaques.

Using a multi-layered approach, we created gene expression maps within a large biobank of advanced carotid lesions $(n=654)$ and studied histological characteristics and the clinical presentation. We report that transcriptome-based analysis of human atherosclerotic lesions identified five plaque clusters linked 
medRxiv preprint doi: https://doi.org/10.1101/2021.11.25.21266855; this version posted November 26, 2021. The copyright holder for this preprint (which was not certified by peer review) is the author/funder, who has granted medRxiv a license to display the preprint in perpetuity. It is made available under a CC-BY-NC-ND 4.0 International license .

to the occurrence of clinical events and biological processes. We highlight a plaque type that is enriched with ACTA2 as well as CD14 expressing cells and with the highest expression of genes involved in neutrophil degranulation, mTOR, iron uptake, and other pathways linked to active inflammatory response and increased expression of genes involved in glycolysis. We verified these findings in coronary artery segments where this plaque type predicted coronary ischemic events. Finally, we did a first pilot study in search for circulating biomarkers that reflect these transcriptomic clusters. Our data demonstrate that a transcriptome based plaque characterization may have significant added value in phenotyping advanced atherosclerotic lesions that lead to clinical symptoms. 


\section{Results}

\section{Athero-Express study cohort of carotid segments}

After quality control, based on measures of RNA library complexity, we have used 654 patients for clustering analysis. From those patients, the accessibility of clinical data resulted in the inclusion of 632 plaques for the prediction models. The baseline characteristics of patients from Athero-Express selected for this plaque study are provided in Supplementary Table 1 . In total, $75.3 \%$ of included patients were males, $24.7 \%$ were females with a mean age of 68.4 years and a mean BMI of $26.6 .43 .2 \%$ of included patients had a stroke, $24.2 \%$ transient ischemic attack, $17.3 \%$ of patients had ocular symptoms, and the remaining $15.3 \%$ were asymptomatic. In 3 -year follow up $13.1 \%$ of patients suffered major adverse cardiovascular events (MACE). Histologically, 30.0\% of included plaques were classified as atheromatous, $32.3 \%$ as fibrous, and $37.7 \%$ as fibro-atheromatous.

\section{Transcriptome-defined molecular plaque types}

To identify groups of patients with similar molecular signatures of advanced atherosclerotic lesion characteristics, we have utilized 654 individual transcriptomes from plaques (Fig. 1a) that passed the QC filters and identified five major molecular plaque types - referred to as \#0, \#1, \#2, \#3 and \#4 (Fig. 1b, Extended Data figure 1ab). All five clusters contain samples with similar numbers of detected proteincoding genes (Extended Data figure 1c). Based on the principal component analysis (PCA) projection and correlation to the most similar sample (Extended Data figure 1c), type \#3 contains more heterogeneous plaques while the other clusters demonstrate higher correlations between the samples. Overall, we did 
medRxiv preprint doi: https://doi.org/10.1101/2021.11.25.21266855; this version posted November 26, 2021. The copyright holder for this preprint (which was not certified by peer review) is the author/funder, who has granted medRxiv a license to display the preprint in perpetuity.

It is made available under a CC-BY-NC-ND 4.0 International license .

not observe clear boundaries between five plaque types, suggesting the presence of intermediate types (Fig. 1b, Extended Data figure 1ab).

The five transcriptomics-based plaque types vastly differ in the expression of numerous candidate marker genes (Fig. 1c, Supplementary Table 2) what supports that the clustering is robust and reflects different underlying biology. For instance, type \#0 plaques show increased expression of FGF13, LPIN1, and KYNU. Type \#1 and \#3 have increased expression of inflammatory molecules and leukocyte markers (CXCL12, $C 1 Q A, C D 14, C D 73$, or $A P O E)$, while \#3 also shows a modestly increased expression of classical smooth muscle cell markers (MYH11, MYH10, and ACTA2). Type \#2 plaques show increased expression of NOS1, SOD2, VDR, SLC35E3, and ATXN3, while they mostly lack expression of immune cells and SMC markers. Finally, type \#4 has the highest expression of classical smooth muscle cell markers (MYH11, MYH10, and ACTA2) and reduced inflammatory and leukocyte marker genes expression.

Next, to understand which molecular processes and pathways underlie the five molecular plaque types, we performed pathway analysis on genes upregulated (based on the differential gene expression analysis) in the individual clusters. Clusters \# $1, \# 3$, and \#4 showed significant enrichment in numerous pathways (Supplementary Table 3). Increased expression of genes involved in neutrophil degranulation, mTOR, iron uptake, and other pathways linked to active inflammatory-response-related processes overlapped with increased expression of glycolysis genes, specifically in type \#3 (Fig. 1de). The same plaque type showed decreased activity of genes involved in fatty acids oxidation, while the activity of the citric acid cycle (TCA cycle) seems to be comparable in all clusters. Similarly, the processes involved in extracellular matrix homeostasis (synthesis, organization, degradation) and cell plasticity (endothelial-mesenchymal transition - EMT) showed specific enrichment in individual plaque types. 
medRxiv preprint doi: https://doi.org/10.1101/2021.11.25.21266855; this version posted November 26, 2021. The copyright holder for this preprint (which was not certified by peer review) is the author/funder, who has granted medRxiv a license to display the preprint in perpetuity.

It is made available under a CC-BY-NC-ND 4.0 International license .

The genes upregulated in plaque types \#0 and \#2 did not show significant enrichment in the pathway analysis. However, the projection of pathways that involve some of the cluster-specific genes (for example, the tryptophan catabolism, which involves L-kynureninase - KYNU) showed increased expression in these specific clusters.

Altogether, the transcriptome-defined plaque types differ in molecular signatures involving metabolism, the inflammatory response, and the process involved in extracellular matrix (ECM) homeostasis. This suggest that the clustering is robust and driven by different underlying biology

\section{Transcriptome-defined molecular plaque types differ in histological and}

\section{cellular composition.}

Of interest, one specific plaque type (\#3) was characterized by gene enrichment pointing to cell types and processes that are commonly used to differentiate between stable and unstable plaques. This type \#3 showed high expression of genes specific for inflammatory cells (like C1QA and CD14) and cells responsible for a fibrotic phenotype (MYH11 and ACTA2). Since the variation in the cellular composition of complex tissues is one of the main drivers of transcriptomic differences, we have analyzed the histological features of the five molecular plaque clusters (Fig 2a). Clusters \#0 and \#4 were significantly enriched in fibrous plaques with lower fat content and increased expression for ACTA2. On the contrary, type \#2 was more enriched in atheromatous plaques, high-fat content, and increased presence of CD68 positive cells. For clusters \#0 to \#4 there was no distinct pattern for the presence of calcification, media remnants, collagen content, and intraplaque hemorrhage (IPH). 
medRxiv preprint doi: https://doi.org/10.1101/2021.11.25.21266855; this version posted November 26, 2021. The copyright holder for this preprint (which was not certified by peer review) is the author/funder, who has granted medRxiv a license to display the preprint in perpetuity.

It is made available under a CC-BY-NC-ND 4.0 International license .

Even though the plaque clusters \#0 and \# 4 showed both absolute and relative increase in ACTA2 positive cells in the histological evaluation, only in plaque-type \#4 was this followed by upregulation of classical SMC markers like ACTA2 or MYH11 in the transcriptomic data (Fig 2b). Similarly, genes involved in ECM organization were downregulated in type \#0 compared to \#4 and \#3.

Since the presence of a specific cell type does not necessarily correlate with individual marker genes, we utilized carotid lesion single-cell RNA-seq based deconvolution (MuSiC algorithm ${ }^{11}$ ), to estimate the relative cell composition of each plaque sample (Fig. 2c). In line with the marker gene expression, plaque clusters \#3 and \#4 showed a higher percentage of ACTA2+ cells relative to type \#0. In line with cell deconvolution, genes overexpressed in type \#0 did not show specific expression in ACTA2+ cells in singlecell transcriptomics data (Fig. 2d); instead, they seemed to be expressed in populations identified as "mixed cells" - a population without a clear cell type-defining expression profile. This mixed plaque type seemed to contain apoptotic myeloid and $T$ cells ${ }^{12}$ and express some of the foam cell drivers $\left(L R P 1 B^{13}\right)$. Altogether, the histologically scored numbers of ACTA2+ cells in plaque type \#0, which resides in a highly fibrotic environment, seems to be overestimated or represents a transcriptionally less active population.

Similarly, the histological evaluation of plaque type \#2 showed the association with increased CD68+ cells. However, the expression of macrophage markers like CD14 and genes involved in inflammatory pathways was predominantly downregulated at the RNA level. Plaques from cluster \#2 also show a lower percentage of macrophages in computationally deconvoluted data. Besides, these cluster-specific genes project to a likely apoptotic "mixed cell" population. It suggests that the residing macrophages in type \#2 plaques have decreased transcriptional activity, or their numbers in the histological evaluation are overestimated. Notably, plaque types do not seem to be driven by the variation in NK-, B- or T-cells content (Fig 2 bd). 
medRxiv preprint doi: https://doi.org/10.1101/2021.11.25.21266855; this version posted November 26, 2021. The copyright holder for this preprint (which was not certified by peer review) is the author/funder, who has granted medRxiv a license to display the preprint in perpetuity.

It is made available under a CC-BY-NC-ND 4.0 International license .

Together, by combining transcriptomics and histological data, we categorized the five plaque clusters as follows: \#0 - fibro-collagenous, \#1 - intermediate, \#2 - lipomatous, \#3 - fibro-inflammatory, and \#4 fibrocellular.

\section{Transcriptome-defined molecular plaque types reflect disease severity.}

Next, to gain clinical insights into the distinct transcriptome-based plaque clusters, we explored the severity of clinical symptoms before the surgery. The clusters \#2, \#3 revealed higher percentages of more severe symptoms - TIA or stroke (80.3\%, 77.0\%, respectively), compared to intermediate \# $1(68.3 \%)$ and less severe $\# 0$ and $\# 4$ (55.8\% and $61.1 \%$ respectively) $(p=0.001)$ (Table 1$)$.

Next, we compared the baseline clinical characteristics in different clusters. We observed a non-random distribution of age (mean 67.2y SD:8.88, 69.1y SD:8.80, 70.4y SD:9.23, 67.5y SD: 8.80 and 68.9y SD: 8.30

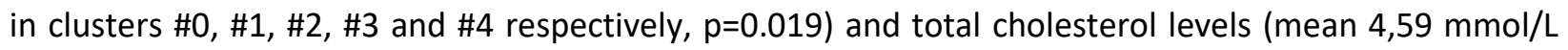
SD:1.27, $4.48 \mathrm{mmol} / \mathrm{L} \mathrm{SD:1.24,} 4.11 \mathrm{mmol} / \mathrm{L}$ SD:1.08, $4.58 \mathrm{mmol} / \mathrm{L} \mathrm{SD}: 1.32$ and $4.44 \mathrm{mmol} / \mathrm{L} \mathrm{SD:} 1.11$ in

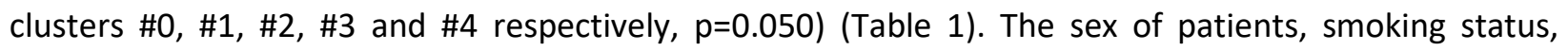
diabetes, hypertension, body mass index, triglycerides, LDL, HDL, and CRP were not significantly different between the transcriptome-driven plaque types - suggesting that the molecular-based clusters cannot be directly approximated from basic clinical demographics. 


\section{Evidence that genetic differences contribute to transcriptome-defined}

\section{molecular plaque types}

Atherosclerosis is a complex disease with a significant genetic component. Up now, GWASs identified over 163 independent genetic loci associated with atherosclerotic disease ${ }^{14}$. We hypothesized that the transcriptome-defined clustering reflects the genetic component of atherosclerotic disease and compared polygenic risk scores (PRS) for coronary artery disease (CAD) ${ }^{15}$. We observed a non-random distribution $(p=0.003)$ with the highest PRS in plaque type \#3 (Fig. 3a). Suggesting that this plaque type is at least partially driven by genetic factors involved in CAD. The expression of genes genetically associated with CAD using gene-based testing $\left(M^{\prime} A G M A^{16}\right)$ showed a similar trend, with the highest expression of CADassociated genes in plaque type \#3 (Fig. 3b).

\section{Coronary artery lesions show similar transcriptomic clustering and}

\section{associate with clinical presentation.}

To investigate whether plaques from other anatomical locations - the coronary arteries, present similar transcriptional profiles, we have repeated the clustering analysis on transcriptomics datasets derived from coronary arteries isolated from heart transplant recipient hearts ${ }^{17}$. We applied the same algorithm as for plaques from carotid arteries. In coronary artery segments, we were able to identify four distinct clusters (Fig. 4ab). Similar to carotids, the individual plaque types in coronary plaques show specific gene expression profiles, molecular pathways, and processes (Fig. 4e). Finally, the four clusters identified in coronary arteries differed in percentages of samples with underlying ischemia $(18.2 \%, 54.9 \%, 6.5 \%$ and $0.0 \%$, respectively) $(p<0.001)$ (Fig. $4 f)$. The cluster with the largest proportion of ischemic samples also 
medRxiv preprint doi: https://doi.org/10.1101/2021.11.25.21266855; this version posted November 26, 2021. The copyright holder for this preprint (which was not certified by peer review) is the author/funder, who has granted medRxiv a license to display the preprint in perpetuity.

It is made available under a CC-BY-NC-ND 4.0 International license .

showed increased expression of genes involved in ECM organization, neutrophil degranulation, TGF-beta signaling, and glycolysis. Notably, these are the same pathways associated with clinical symptoms in bulk transcriptomic analyses of carotid plaques in plaque type \#3 (Fig. 1d).

Since the coronary samples comprise the entire artery, including adventitial tissue, the four clusters identified in coronaries cannot be directly compared to the clusters from carotid arteries. Therefore, we aimed to identify the most similar carotid sample for each sample from coronary arteries. We have first employed the anchor-based data integration algorithm, which allows merging datasets with different confounders $^{18}$. Next, we identified the best matching carotid sample to each coronary using the Pearson correlation (Fig. 4cd) and assigned the corresponding clusters.

The samples assigned to the same clusters again show the specific molecular pathway activity (like neutrophil degranulation or glycolysis) (Fig. 4g) and correlated with clinical manifestation (Fig. 4h). The best matching coronary samples for the patients detected in the symptomatic carotid plaque type \#3 were observed in coronary cluster\#1, which is the plaque type with the highest prevalence of ischemic cardiac disease. This suggests that the plaque types identified in this study and their connection to the plaque's clinical manifestation translate to other cohorts and anatomical localizations.

\section{Circulating biomarkers correlate with transcriptomic clusters}

A novel description and categorization of 'vulnerable' plaque types that goes beyond the scope of histopathological phenotyping is of great value for the scientific community in the field of vascular biology. However, for this novel type of patient and plaque stratification should be translated into tangible results

- like circulating biomarkers applicable in a clinical setting. For clinical translation, we analyzed 
medRxiv preprint doi: https://doi.org/10.1101/2021.11.25.21266855; this version posted November 26, 2021. The copyright holder for this preprint (which was not certified by peer review) is the author/funder, who has granted medRxiv a license to display the preprint in perpetuity.

It is made available under a CC-BY-NC-ND 4.0 International license .

cardiovascular OLINK biomarker panels in available blood samples of 208 patients, searching for circulating biomarkers that associate the different transcriptomic clusters.

Out of 264 blood-derived biomarkers, we found that 10 were nominally associated with patho-histological plaque type (atheromatous, fibroatheromatous, or atheromatous) and 10 with the presence of calcifications (Fig. 5a). However, 28 circulating biomarkers showed significantly different levels among transcriptomic plaque clusters (Fig. 5a). Notably, the PDGF subunit $B(\mathrm{p}=0.005)$ showed the highest plasma levels in patients from plaque type \#0. This growth factor is a potent activator of proliferation in cells of mesenchymal origin, and its receptor was recently shown to induce SMC-to- myofibroblast transitions in an aerobic glycolysis-dependent manner ${ }^{19}$ (Fig 5b). Another marker SLAMF7 showed the highest plasma levels in patients with plaque type \#2. Previously it was shown that the depletion of SLAMF7 in plaquederived macrophages induced a suppressed secretion of proinflammatory cytokines, and inhibited proliferation of vascular smooth muscle cells ${ }^{20}$. This altogether suggests that the presence of distinct transcriptome-defined plaque types can be proxied by relevant circulating biomarkers.

\section{Discussion}

In the present study, using the unsupervised clustering, we describe five transcriptomic clusters in carotid plaques that relate to biological pathways and clinical presentation. Pathways that appeared overrepresented in a plaque type with more vulnerable patients pointed towards, among others, neutrophil degranulation, matrix organization, and glycolysis. 
medRxiv preprint doi: https://doi.org/10.1101/2021.11.25.21266855; this version posted November 26, 2021. The copyright holder for this preprint (which was not certified by peer review) is the author/funder, who has granted medRxiv a license to display the preprint in perpetuity.

It is made available under a CC-BY-NC-ND 4.0 International license .

Atherosclerosis is a chronic lipid and inflammation-driven disease that develops and progresses over decades $^{21,22}$. The natural history of atherosclerotic plaque progression and stabilization is mainly unknown, and strikingly, the currently applied plaque description of the 'vulnerable plaque' has been initially based on pathology studies that reflect the worst cases, those who died ${ }^{1,2,23}$. The pathology-based concepts of the 'vulnerable plaque' have provided invaluable insights that have dominated vascular biology research for decades. Pathological observations have also shown the heterogeneity of vascular lesions that can lead to an adverse event. Plaque rupture has long been considered the pathological substrate leading to an acute thrombotic occlusion of the artery and described the lipid-rich, atheromatous, plaque with a thin fibrous cap with local infiltration of inflammatory cells that cause proteolytic activity and degradation of the stabilizing stimulate extracellular matrix. The mechanisms that underlie superficial erosion, a cause of coronary thrombosis distinct from plaque rupture, have garnered increasing interest ${ }^{23-25}$. In an era of improved control of traditional risk factors, plaque erosion assumes greater clinical importance ${ }^{26}$. Besides, the widely available analyses of genomic variants revealed novel and unexplored causal genes associated with the occurrence of acute atherosclerotic cardiovascular events $^{27}$. The observation of thrombotic occlusion on an unruptured plaque ${ }^{24}$ and the role of microcalcifications ${ }^{28}$ destabilizing the cap made it clear that there is not one unambiguous description characterizing all unstable atherosclerotic lesions. The limitations of the current conceptual description of the 'vulnerable plaque' are also shown by the hallmark PROSPECT study that examined the natural history of advanced atherosclerotic lesions by serial intravascular imaging. There it was demonstrated that the predictive value of a thin capped fibro-atheromatous plaque is only $5 \%$ for the development of an adverse myocardial event. This increases to $20 \%$ if the presence of expansive remodeling and plaque cross-sectional area is taken into account ${ }^{29,30}$.

The acceleration of RNA sequencing efforts of human atherosclerotic lesions provides an opportunity to fine-tune the description of the plaque at risk for a thrombotic event ${ }^{12,31,32}$. 
medRxiv preprint doi: https://doi.org/10.1101/2021.11.25.21266855; this version posted November 26, 2021. The copyright holder for this preprint (which was not certified by peer review) is the author/funder, who has granted medRxiv a license to display the preprint in perpetuity.

It is made available under a CC-BY-NC-ND 4.0 International license .

\section{Pathology and transcriptome-based plaque characterization.}

Our transcriptomic data indicate the existence of plaque types that partly overlap with the pathological characterization and are associated with clinical symptoms of ischemic stroke and myocardial ischemia. Our analyzes also provide insight into cell-specific processes that can play a role in the destabilization of the plaque. Surprisingly, carotid plaques in plaque type \#3, with the most severe symptoms and with the best match with symptomatic coronary plaques, showed enrichment of pathways and RNA-based cell types that are traditionally categorized in two distinct plaque categories. This plaque type revealed an abundance of the smooth muscle cell and macrophage-specific genes, cell types that in pathology and animal experimental categorizations are often considered as "stabilizing" and "destabilizing", respectively. Our transcriptomic analyses confirm the existence of a complex landscape of atherosclerotic lesion phenotypes that associate with clinical symptoms. The inferences regarding the risk of clinical thrombotic events based on pathological therefore merit careful (re)consideration. Projection of the coronary transcriptome clusters onto the carotid cluster analysis showed substantial overlap.

\section{Transcriptomic clustering points to plaque molecular phenotypes that associate with increased} risk for ischemic events.

In both carotid and coronary plaques, there was a strong distinction between clusters in the expression of genes annotated to different molecular pathways.

Pathways indicating neutrophil activation, glycolysis, extracellular matrix organization, and iron uptake and transport were strongly over-represented in both arteries in the same cluster that was also associated with clinical events. This plaque type showed an overrepresentation of CXCL12, CD14, C1QA, CD63, CD74, $A P O E$; genes that are often observed in plaque-derived macrophages. Indeed, deconvolution of the bulk sequencing data, using the cell-based transcripts from the single-cell sequencing, demonstrated that a 
medRxiv preprint doi: https://doi.org/10.1101/2021.11.25.21266855; this version posted November 26, 2021. The copyright holder for this preprint (which was not certified by peer review) is the author/funder, who has granted medRxiv a license to display the preprint in perpetuity.

It is made available under a CC-BY-NC-ND 4.0 International license .

significant proportion of the transcripts in this plaque type pointed to monocyte/macrophage lineages

(Fig. 2cd).

The role of neutrophil activation in plaque stabilization has long been underestimated, but the discovery that neutrophil extracellular traps (NETs) may have a causal role in plaque destabilization confirms a potential role of genes indicating neutrophil activation ${ }^{33-35}$. Using in vivo and in vitro assays, Soehnlein and colleagues showed that activated SMCs in atherosclerotic plaques release chemotactic factors that attract neutrophils and trigger the release of NETs containing histone $\mathrm{H} 4$, which has cytotoxic effects on $\mathrm{SMCs}^{36}$. In addition, it has been shown that neutrophil microvesicles accumulate at disease-prone regions of arteries exposed to disturbed flow patterns and promote vascular inflammation and atherosclerosis in a murine model ${ }^{37}$.

The role of metabolic pathways such as glycolysis ${ }^{38}$, fatty acid oxidation, and tryptophan catabolism may point to phenotype switching of vascular cells ${ }^{19}$. The differentiation of a contractile to a synthetic myofibriblast-like phenotype in smooth muscle cells is driven by switching from oxidative to glycolytic metabolism ${ }^{39}$. In endothelial cells, glycolysis is essential for ATP production and sprouting of vessels since the loss of the glycolytic activator PFKFB3 in ECs impairs vessel formation ${ }^{40}$. In addition, enhanced glycolysis has been recognized as a critical role in initiating endothelial or epithelial to mesenchymal transition (EMT) progression ${ }^{41}$. Smooth muscle cell and endothelial cell differentiation are mediated by local inflammation. The increased activity of the glycolysis pathway may thus relate to an active state of cell types that differentiate and accommodate to an unstable (inflammatory) environment.

The role of iron uptake in atherosclerosis has been debated and is considered multifaceted. Iron can cause oxidative damage by lipid peroxidation, and oxidized lipoprotein can then be taken up by the LDL 
medRxiv preprint doi: https://doi.org/10.1101/2021.11.25.21266855; this version posted November 26, 2021. The copyright holder for this preprint (which was not certified by peer review) is the author/funder, who has granted medRxiv a license to display the preprint in perpetuity.

It is made available under a CC-BY-NC-ND 4.0 International license .

receptor on macrophages leading to their development into foam cells (reviewed in ${ }^{42}$ ). On the other hand, CD163+ alternative macrophages engulfing the hemoglobin-haptoglobin complexes $(\mathrm{HH})$ were shown to augments hyaluronan synthesis in vascular SMCs and preventing vascular calcification ${ }^{43}$.

Genes overexpressed in the plaque transcriptomic type that predicted stroke and cardiac ischemia (like CD14) support the involvement of inflammation in this high-risk plaque. CXCL12 is one of the genes that is also recognized in a GWAS for coronary artery disease ${ }^{44} . C D 63$ is a protein that is mainly associated with the membrane of intracellular vesicles and is also used as a marker for blood platelet activation ${ }^{45}$ as well as circulating vesicles ${ }^{46}$ and functionally plays a role in signal transduction. C1QA is considered to play a role in removing apoptotic cells via efferocytosis, and its presence reduces the atherosclerotic plaque size in animal models ${ }^{47}$.

\section{Clinical value of transcriptomic-based plaque characterization.}

The pathology-based description of the 'vulnerable plaque' has proven crucial value for understanding the progression and complications of atherosclerotic disease in experimental research ${ }^{48}$. In addition, the clinical utility of numerous vascular imaging modalities is based on the well-known definition of thin cap fibroatheroma. The discovery and evaluation of pharmaceutical treatments rely on animal models that apply the pathology-based surrogate measures of destabilizing atherosclerotic disease. Our observations provide evidence that transcriptomic profiling and subsequent clustering of human plaques may have substantial added value in searching for suitable drug targets. These observations that significantly finetune the phenotype of the destabilizing plaque can be translated to animal models and cell culture systems used in drug-related research. 
medRxiv preprint doi: https://doi.org/10.1101/2021.11.25.21266855; this version posted November 26, 2021. The copyright holder for this preprint (which was not certified by peer review) is the author/funder, who has granted medRxiv a license to display the preprint in perpetuity.

It is made available under a CC-BY-NC-ND 4.0 International license .

There is an unmet need for biomarkers associated with the presence of plaques at risk for a thrombotic ischemic event. Proteins can today be measured with high accuracy using multiplex methods ${ }^{49}$. We feel that the observed enrichment of biomarkers associated with different transcriptomic plaque clusters is promising. Our sample size with combined plaque transcriptomic and clinical data does not allow strong inferences and surely requires verification. Our data do show that non-stratified biomarker analyses in large pooled patient samples may mask subgroups in whom biomarker profiles could be predictive. For example, clusters \#0 and \#4 both encompassed patients with mild symptoms but had different associations with biomarker profiles.

In summary, our study shows that deciphering the transcriptomic profile of atherosclerotic lesions results in an updated description of the 'vulnerable plaque' with clinical relevance. Our results also demonstrate that transcriptomic analyses can contribute to assessing lesion phenotypes that are predisposed to a thrombotic event and potentially reveal underlying pathogenetic mechanisms.

\section{Methods}

\section{Carotid plaque samples}

The Athero-Express Biobank $(\mathrm{AE})$ includes patients undergoing carotid endarterectomy, of which the study design has been published before ${ }^{50,51}$. The AE study is an ongoing biobank, and extensive baseline characteristics, blood samples, and atherosclerotic plaque specimens are collected. Clinical data were obtained from patient files and through standardized questionnaires. The indication for CEA was based on the recommendations from the Asymptomatic Carotid Surgery Trial (ACST) for asymptomatic patients and the European Carotid Surgery Trial (ECST) and North American Symptomatic Carotid Endarterectomy 
medRxiv preprint doi: https://doi.org/10.1101/2021.11.25.21266855; this version posted November 26, 2021. The copyright holder for this preprint (which was not certified by peer review) is the author/funder, who has granted medRxiv a license to display the preprint in perpetuity.

It is made available under a CC-BY-NC-ND 4.0 International license .

Trial for symptomatic patients (NASCET). Indications for CEA were evaluated by a multidisciplinary vascular team. The removal of atherosclerotic plaques was performed by a team of experienced surgeons, and standardized treatment protocols were applied. All patients were examined by a neurologist for assessment of their preoperative neurologic status. For this study, subsequent patients were included who underwent carotid endarterectomy between 2002 and 2016 and of whom genotyping data were available. The performed study is in line with the Declaration of Helsinki and informed consent was provided by all study participants after the approval for this study by medical ethical committees of the different hospitals was obtained.

\section{Baseline characteristics}

Baseline data were obtained by chart review and from extensive questionnaires completed by the participating patients that included questions on the history of cardiovascular disease, cardiovascular risk factors (smoking, hypertension, diabetes), and use of medication. Presenting symptoms and duplex stenosis were retrieved from patient charts. Symptom categories were "asymptomatic", defined as not having ipsilateral cerebrovascular symptoms in the previous 6 months; "ocular" - amaurosis fugax, defined as ipsilateral mono-ocular blindness of acute onset lasting < 24 hours; cerebral "transient ischemic attack" (TIA), defined as the ipsilateral focal neurologic deficit of acute onset lasting < 24 hours; and ipsilateral "stroke". Lipid spectra were determined in blood specimens drawn at baseline.

\section{Follow up}

All patients answered a questionnaire 1, 2, and 3 years after the carotid endarterectomy. In case an adverse event was reported or suspected, the referring hospital or general practitioner was approached for additional medical information. The primary outcome was defined as a composite of endpoints including, any death of vascular origin (fatal stroke, fatal myocardial infarction, sudden death, and other 
medRxiv preprint doi: https://doi.org/10.1101/2021.11.25.21266855; this version posted November 26, 2021. The copyright holder for this preprint (which was not certified by peer review) is the author/funder, who has granted medRxiv a license to display the preprint in perpetuity.

It is made available under a CC-BY-NC-ND 4.0 International license.

vascular death), non-fatal stroke (either ischemic or hemorrhagic) or non-fatal myocardial infarction, and any arterial vascular intervention that had not already been planned at the time of inclusion (e.g. carotid surgery or angioplasty, coronary artery bypass, percutaneous coronary artery intervention, peripheral vascular surgery, or angioplasty).

\section{Sample handling}

The atherosclerotic plaques were transported to the laboratory and processed immediately after the surgical removal. An experienced technician identified the culprit lesion, which is defined as the segment with the smallest lumen. In case of doubt, the segment with the largest plaque diameter was selected. The segment with the culprit lesion was then prepared and stored in $4 \%$ formaldehyde, decalcified, and embedded in paraffin for histological analysis. The rest of the plaque was snap-frozen using liquid nitrogen and stored at -80 degrees Celsius.

\section{Histological assessment}

The assessment was performed according to a previously validated protocol, which was described in detail before $^{52,53}$. In brief, cross-sections of the culprit lesion are stained and quantified for each patient. A hematoxylin-eosin (HE) staining was performed for the assessment of calcification, picrosirius red for collagen and alpha-smooth muscle actin for smooth muscle cells. CD68 was stained to identify macrophages. The location of SMCs was evaluated as "mainly basal", "homogeneous," and" mainly luminal". The location of macrophages was evaluated as "basal", "homogeneous", "luminal", or "no macrophages". Plaque characteristics were scored semi-quantitatively at 40x magnification and grouped into no, minor, moderate and heavy staining. In the present study, these categories were binned into no/minor staining and moderate/heavy staining. Immunohistochemical staining for CD34 was performed to assess vessel density. Plaque microvessels were quantified in three hotspots and subsequently, the 
medRxiv preprint doi: https://doi.org/10.1101/2021.11.25.21266855; this version posted November 26, 2021. The copyright holder for this preprint (which was not certified by peer review) is the author/funder, who has granted medRxiv a license to display the preprint in perpetuity.

It is made available under a CC-BY-NC-ND 4.0 International license .

average number of vessels per hotspot was calculated. Picrosirius red in combination with elastic-Van Gieson, $\mathrm{HE}$ and polarized light was used to visualize the lipid core. The lipid content of the plaque was estimated as a percentage of the total plaque area, with a cutoff at $10 \%$ and $40 \%$ for carotid plaques. Plaques with $<10 \%, 10-40 \%$ and $>40 \%$ fat were categorized as fibrous, fibro-atheromatous and atheromatous, respectively. The presence of plaque hemorrhage was determined using HE staining, fibrin staining and glycophorin staining. All plaque characteristics were scored and quantified with good intraand interobserver reproducibility by two independent observers ${ }^{52}$.

\section{RNA isolation and library preparation}

A total of 700 segments were selected from patients who were included in the study between 2002 and 2016. The RNA isolated from the archived advanced atherosclerotic lesion is fragmented (Extended Data figure 2a). We have, therefore, tested four different library preparation strategies (Extended Data figure 2bc): CEL-seq2 ${ }^{54}$, QIAseq (QIAseq Stranded Total RNA Lib Kit, Qiagen), NEXTflex (NEXTflex Rapid Directional RNA-Seq Kit, Bioo Scientific) and SMARTer (SMARTer ${ }^{\circledR}$ Stranded RNA-Seq Kit, Takara) using the manufacturer's or author's recommendations. We have ultimately employed the CEL-seq2 method ${ }^{54}$. CELseq2 yielded the highest mappability reads to the annotated genes compared to other library preparation protocols (Extended Data figure $2 \mathrm{bc}$ ). The methodology captures $3^{\prime}$-end of polyadenylated RNA species and includes unique molecular identifiers (UMIs), which allow direct counting of unique RNA molecules in each sample. 50ng of total RNA was precipitated using isopropanol and washed with $75 \%$ ethanol. After removing ethanol and air-drying the pellet, primer mix containing 5ng primer per reaction was added, initiating primer annealing at $65^{\circ} \mathrm{C}$ for $5 \mathrm{~min}$. Subsequent RT reaction was performed; first strand reaction for $1 \mathrm{~h}$ at $42^{\circ} \mathrm{C}$, heat-inactivated for $10 \mathrm{~m}$ at $70^{\circ} \mathrm{C}$, second strand reaction for $2 \mathrm{~h}$ at $16^{\circ} \mathrm{C}$, and then put on ice until proceeding to sample pooling. The primer used for this initial reverse-transcription (RT) reaction was designed as follows: an anchored polyT, a unique $6 \mathrm{bp}$ barcode, a unique molecular identifier (UMI) 
medRxiv preprint doi: https://doi.org/10.1101/2021.11.25.21266855; this version posted November 26, 2021. The copyright holder for this preprint (which was not certified by peer review) is the author/funder, who has granted medRxiv a license to display the preprint in perpetuity.

It is made available under a CC-BY-NC-ND 4.0 International license .

of $6 \mathrm{bp}$, the 5' Illumina adapter and a T7 promoter, as described. Each sample now contained its own unique barcode due to the primer used in the RNA amplification, making it possible to pool together cDNA samples at 7 samples per pool. Complementary DNA (cDNA) was cleaned using AMPure XP beads (Beckman Coulter), washed with $80 \%$ ethanol, and resuspended in water before proceeding to the in vitro transcription (IVT) reaction (AM1334; Thermo-Fisher) incubated at $37^{\circ} \mathrm{C}$ for 13 hours. Next, primers were removed by treating with Exo-SAP (Affymetrix, Thermo-Fisher) and amplified RNA (aRNA) was fragmented and then cleaned with RNAClean XP (Beckman-Coulter), washed with 70\% ethanol, air-dried, and resuspended in water. After removing the beads using a magnetic stand, RNA yield and quality in the suspension were checked by Bioanalyzer (Agilent).

cDNA library construction was then initiated by performing an RT reaction using SuperScript II reverse transcriptase (Invitrogen/Thermo-Fisher) according to the manufacturer's protocol, adding randomhexRT primer as a random primer. Next, PCR amplification was done with Phusion High-Fidelity PCR Master Mix with HF buffer (NEB, MA, USA) and a unique indexed RNA PCR primer (Illumina) per reaction, for a total of 11-15 cycles, depending on aRNA concentration, with 30 seconds elongation time. PCR products were cleaned twice with AMPure XP beads (Beckman Coulter). Library cDNA yield and quality were checked by Qubit fluorometric quantification (Thermo-Fisher) and Bioanalyzer (Agilent), respectively. Libraries were sequenced on the Illumina Nextseq500 platform; paired end, $2 \times 75 \mathrm{bp}$.

\section{Sequencing read mapping and quality filtering}

Libraries were sequenced on the Illumina Nextseq500 platform; a high output paired-end run of $2 \times 75$ bp was performed (Utrecht Sequencing Facility). The reads were demultiplexed and aligned to human cDNA reference (Ensembl 84) using the BWA (0.7.13) by calling 'bwa aln' with settings -B 6 -q 0 -n 0.00 -k 2 -I 200 -t 6 for R1 and -B 0 -q 0 -n 0.04 -k 2 - I 200 -t 6 for R2, 'bwa sampe' with settings -n 100 -N 100. Multiple reads mapping to the same gene with the same unique molecular identifier (UMI, 6bp long) were counted 
medRxiv preprint doi: https://doi.org/10.1101/2021.11.25.21266855; this version posted November 26, 2021. The copyright holder for this preprint (which was not certified by peer review) is the author/funder, who has granted medRxiv a license to display the preprint in perpetuity.

It is made available under a CC-BY-NC-ND 4.0 International license .

as a single read. The raw read counts were corrected for UMI sampling (corrected_count $=-4096 *(\operatorname{In}(1$ (raw_count/4096)))), normalized for sequencing depth and quantile normalized. We have detected a median of 19.501 ( $S D=5.874)$ genes per sample with at least one unique read (Extended Data figure $2 \mathrm{~d}$ ) and discarded samples $(n=46)$ with less than 9000 detected genes from further analysis (Extended Data figure 2e and Fig 1a). For all the subsequent analyses, we have excluded all the ribosomal genes and used only the protein-coding genes with annotated HGCN names.

\section{Clustering of transcriptomics datasets}

Clustering of datasets from carotid arteries was based on the first 12 principal components (PCs) calculated using 5000 most variable genes from the normalized gene expression data. We used the shared nearest neighbor (SNN) modularity optimization-based clustering algorithm ${ }^{55}$ implemented in the Seurat package $^{18}$ (core scripts can be found at https://github.com/CirculatoryHealth/PlaqueCluster). 162 transcriptomics data sets from coronary arteries were clustered separately in the same way.

\section{Pathway analysis}

Pathway analysis was performed using the "ReactomePA" R/Bioconductor package ${ }^{56}$. Module score were calculated using the Seurat's AddModuleScore() function.

\section{Baseline characteristics tables}

Baseline characteristics tables were produced using R's "tableone" package with default settings. Statistical significance of differences between groups was tested using the chi-square test for categorical 
medRxiv preprint doi: https://doi.org/10.1101/2021.11.25.21266855; this version posted November 26, 2021. The copyright holder for this preprint (which was not certified by peer review) is the author/funder, who has granted medRxiv a license to display the preprint in perpetuity.

It is made available under a CC-BY-NC-ND 4.0 International license .

variables and one-way analysis of variance (ANOVA) for continuous variables (with equal variance assumption, i.e., regular ANOVA).

\section{Cell Deconvolution Analysis}

We deconvoluted the gene expression of 632 advanced carotid plaques into cell composition matrices using the MUSIC deconvolution method with default parameter ${ }^{11}$ based on a single cell RNAseq data from advanced carotidatherosclerotic plaques ${ }^{12}$. We merged all the sub-cell types into 7 cell types ('CD14+CD68+ Macrophages','CD34+ Endothelial Cells','CD3+CD4+ T Cells','CD3+CD8+ T Cells','CD79A+ BCells','KIT+ Mast Cells','ACTA2+ Smooth Muscle Cells) and removed mixed cells.

\section{Human coronary artery tissue procurement}

Ischemic human coronary artery tissue biospecimens were obtained at Stanford University from diseased heart transplant donors consenting for research studies. Hearts were arrested in cardioplegic solution and transported on ice prior to dissecting proximal coronary artery segments from main branches of left anterior descending, circumflex or right coronary arteries. Epicardial and perivascular adipose was trimmed on ice, rinsed in cold phosphate-buffered saline, and rapidly frozen in liquid nitrogen, and stored at -80C. Normal human coronary artery tissue biospecimens were also obtained at Stanford University from non-diseased donor hearts rejected for orthotopic heart transplantation processed following the same protocol as hearts for transplant. Tissues were de-identified and clinical and histopathology information was used to classify ischemic and non-ischemic arteries. All normal arteries originated from hearts with a left ventricular ejection fraction (LVEF) greater than $50 \%$. Frozen tissues were transferred to the University of Virginia through a material transfer agreement and Institutional Review Board-approved protocols. 
medRxiv preprint doi: https://doi.org/10.1101/2021.11.25.21266855; this version posted November 26, 2021. The copyright holder for this preprint (which was not certified by peer review) is the author/funder, who has granted medRxiv a license to display the preprint in perpetuity.

It is made available under a CC-BY-NC-ND 4.0 International license .

\section{RNA Extraction, QC, library construction and sequencing of coronary samples}

Total RNA was extracted from frozen coronary artery segments using the Qiagen miRNeasy Mini RNA Extraction kit (catalog \#217004). Approximately $50 \mathrm{mg}$ of frozen tissue was pulverized using a mortar and pestle under liquid nitrogen. Tissue powder was then further homogenized in Qiazol lysis buffer using stainless steel beads in a Bullet Blender (Next Advance) homogenizer, followed by column-based purification. RNA concentration was determined using Qubit 3.0 and RNA quality was determined using Agilent 4200 TapeStation. Samples with RNA Integrity Number (RIN) greater than 5.5 and Illumina DV 200 values greater than 75 were included for library construction. Total RNA libraries were constructed using the Illumina TruSeq Stranded Total RNA Gold kit (catalog \#20020599) and barcoded using Illumina TruSeq RNA unique dual indexes (catalog \# 20022371). After re-evaluating library-quality using TapeStation, individually barcoded libraries were sent to Novogene for next-generation sequencing. After passing additional QC, libraries were multiplexed and subjected to paired-end $150 \mathrm{bp}$ read sequencing on an Illumina NovaSeq S4 Flowcell to a median depth of 100 million total reads (>30 G) per library.

\section{RNA-seq processing and analysis of coronary samples}

The raw passed filter sequencing reads obtained from Novogene were demultiplexed using the bcl2fastq script. The quality of the reads was assessed using FASTQC and the adapter sequences were trimmed using trimgalore. Trimmed reads were aligned to the hg38 human reference genome using STAR v2.7.3a according to the GATK Best Practices for RNA-seq. To increase mapping efficiency and sensitivity, novel splice junctions discovered in a first alignment pass with high stringency were used as annotation in a second pass to permit lower stringency alignment and therefore increase sensitivity. PCR duplicates were marked using Picard and WASP was used to filter reads prone to mapping bias. Total read counts and RPKM were calculated with RNA-SeQC v1.1.8 using default parameters and additional flags "-n 1000 noDoC -strictMode" and GENCODE v30 reference annotation. 


\section{Projection of coronary artery datasets with carotid based clusters}

To integrate two heterogeneous datasets, we have first used the anchor-based data integration algorithm

${ }^{18}$. Next, we have created a pairwise correlation matrix between individual samples using the Pearson correlation. Then for each coronary sample, we have assigned the cluster identity of the closest (best positively correlated) carotid sample.

\section{Measurement of circulating biomarkers}

In 208 selected patients from AtheroExpress cohort, we used a commercially available multiplex proximity extension assay ${ }^{57}$ from Olink proteomics AB platform (Uppsala, Sweden) to measure 264 proteins using the Olink ${ }^{\circledast}$ Cardiovascular II, Olink ${ }^{\circledast}$ Cardiovascular III, and Olink ${ }^{\circledast}$ Cardiometabolic panels. These panels were selected for their known associations with CV disease. Proteins are expressed on a log2- scale as normalized protein expression (NPX) values. Patients were randomly distributed across plates.

\section{Genotyping, imputation and weighted polygenic scores calculation}

\section{DNA isolation and genotyping}

We genotyped the AE in three separate but consecutive experiments ${ }^{58}$. The DNA was extracted from EDTA blood or (when no blood was available) plaque samples using in-house validated protocols and genotyped in 3 batches (Athero-Express Genomics Studies). For the Athero-Express Genomics Study 1 (AEGS1), included between 2002 and 2007, were genotyped (440,763 markers) using the Affymetrix Genome-Wide Human SNP Array 5.0 (SNP5) chip (Affymetrix Inc., Santa Clara, CA, USA) at Eurofins Genomics, https://www.eurofinsgenomics.eu/). For the Athero-Express Genomics Study 2 (AEGS2), included 
medRxiv preprint doi: https://doi.org/10.1101/2021.11.25.21266855; this version posted November 26, 2021. The copyright holder for this preprint (which was not certified by peer review) is the author/funder, who has granted medRxiv a license to display the preprint in perpetuity.

It is made available under a CC-BY-NC-ND 4.0 International license.

between 2002 and 2013, were genotyped (587,351 markers) using the Affymetrix Axiom $\mathbb{R}$ GW CEU 1 Array (AxM) at the Helmholtz Genome Analysis Center (https://www.helmholtzmuenchen.de/no cache/gac/index.html). For the Athero-Express Genomics Study 3 (AEGS3), included between 2002 and 2016, were genotyped (693,931 markers) using the Illumina GSA MD v1 BeadArray (GSA) at Human Genomics Facility, HUGE-F (http://glimdna.org/index.html). All experiments were carried out according to OECD standards and as advised by the respective manufacturer. We used the genotyping calling algorithms as advised by Affymetrix (BRLMM-P for AEGS1 and AxiomGT1 for AEGS2) and Illumina (Illumina GenomeStudio For AEGS3).

\section{Quality control after genotyping}

After genotype calling, we adhered to community standard quality control and assurance (QCA) procedures of the genotype data from AEGS1, AEGS2, and $A E G S 3^{59}[R E F]$. Samples with low average genotype calling and sex discrepancies (compared to the clinical data available) were excluded. The data was further filtered on: 1) individual (sample) call rate $>97 \%$, 2) SNP call rate $>97 \%, 3$ ) minor allele frequencies (MAF) > 3\%, 4) average heterozygosity rate \pm 3.0 cs.d., 5) relatedness (pi-hat >0.20), 6) HardyWeinberg Equilibrium (HWE $\left.\mathrm{p}<1.0 \times 10^{-3}, 7\right)$ Monomorphic SNPs $\left(\mathrm{MAF}<1.0 \times 10^{-6}\right.$ ), and 8 ) deviation in the principal component analysis plot using $1000 \mathrm{G}$ phase 3 as reference (6 iterations \pm 3 s.d.).

\section{Imputation}

Before phasing using SHAPEIT2 ${ }^{60}$, data was lifted to genome build b37 using the liftOver tool from UCSC (https://genome.ucsc.edu/cgi-bin/hgLiftOver). Finally, data were imputed with 1000G phase 3, version 5 and HRC release 1.1 as a reference using the Michigan Imputation Server (https://imputationserver.sph.umich.edu/). These results were further integrated using QCTOOL v2 (https://www.well.ox.ac.uk/ gav/qctool_v2/), where HRC imputed variants are given precedence over 
medRxiv preprint doi: https://doi.org/10.1101/2021.11.25.21266855; this version posted November 26, 2021. The copyright holder for this preprint (which was not certified by peer review) is the author/funder, who has granted medRxiv a license to display the preprint in perpetuity.

It is made available under a CC-BY-NC-ND 4.0 International license .

$1000 \mathrm{G}$ phase 3 imputed variants. After imputation, we compared the quality of the three AEGS datasets based on sample type (EDTA blood or plaque) and genotyping chip used. We checked identity-by-descent (IBD) within and between datasets to aid in sample mixups, duplicate sample use, and relatedness.

\section{Weighted polygenic score calculation}

We estimated the weighted polygenic cardiovascular disease susceptibility using the previously published polygenic risk score for coronary artery disease (MetaGRS) described before ${ }^{61}$. Briefly, the MetaGRS comprises 1,745,179 genetic variants with a minor allele frequency (MAF) $>0.1 \%$ associated with CAD and was constructed through meta-analysis of three genomic risk scores: GRS46K (comprising 46,000 cardiometabolic genetic variants), FDR202 (including 202 genetic variants associated with CAD at false discovery rate $p<0.05$ in the recent GWAS CARDIoGRAMplusC4D), and the 1000 Genomes genetic score also created with CARDIoGRAMplusC4D. The MetaGRS was internally and externally validated for the primary risk of prevalent and incident CAD in the UK Biobank ${ }^{61}$. We matched the 1.7 million variants from the MetaGRS to $1,742,593$ variants in our data (2586 variants were not present in our data). Given that the median imputation quality was high (INFO = 0.978 [IQR 0.945-0.991]), and the variants included in the MetaGRS have MAF $>0.1 \%$, we did not further filter on imputation quality. Moreover, since we used the imputed genotype probabilities to calculate the MetaGRS, rather than the hard-coded genotypes, bias arising from imputation error, i.e., low imputation quality, will only reduce predictive accuracy. Thus, we calculated the weighted polygenic score (PGS) for each included patient in this study using PRSice- $2^{62}$ as follows. To account for the imputation quality, we used the allelic dosages $(D)$ estimated by IMPUTE2 based on the posterior genotype probabilities $\left(P_{g}\right)$ for the B-allele $(\mathrm{B})$ for the $i^{\text {th }}$ variant. Thus:

$D_{i}=2 \times P_{g}(\mathrm{BB})+1 \times P_{g}(\mathrm{AB})+0 \times P_{g}(\mathrm{AA})$ 
medRxiv preprint doi: https://doi.org/10.1101/2021.11.25.21266855; this version posted November 26, 2021. The copyright holder for this preprint (which was not certified by peer review) is the author/funder, who has granted medRxiv a license to display the preprint in perpetuity. It is made available under a CC-BY-NC-ND 4.0 International license .

For each individual, we calculated the aggregate polygenic scores using the effect $D$ of all modeled variants weighted by the effect size $(\beta)$ of the $i^{\text {th }}$ variant as given in the MetaGRS. Thus, for each individual $n$, the weighted PGS is the sum of the $\beta$ of the $i^{\text {th }}$ variant multiplied by the dosage $D$ of that respective variant:

$$
\text { polygenic score }=\sum_{i}^{n} \beta_{i} \times D_{i}
$$

We standardized the PGS to mean-zero and unit-variance for each genotyping batch separately. 
medRxiv preprint doi: https://doi.org/10.1101/2021.11.25.21266855; this version posted November 26, 2021. The copyright holder for this preprint (which was not certified by peer review) is the author/funder, who has granted medRxiv a license to display the preprint in perpetuity.

It is made available under a CC-BY-NC-ND 4.0 International license .

\section{Figures}


medRxiv preprint doi: https://doi.org/10.1101/2021.11.25.21266855; this version posted November 26, 2021. The copyright holder for this preprint (which was not certified by peer review) is the author/funder, who has granted medRxiv a license to display the preprint in perpetuity.

It is made available under a CC-BY-NC-ND 4.0 International license .

a

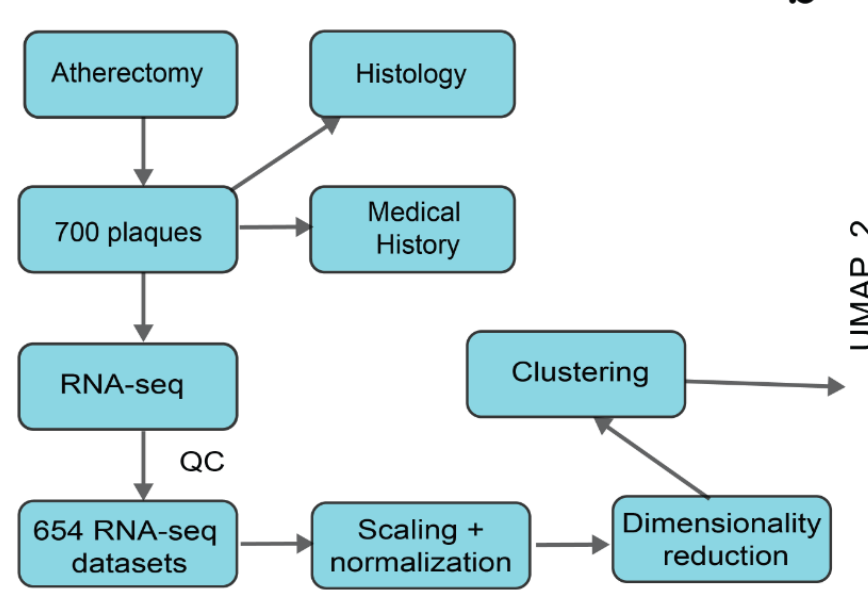

Plaque type \#

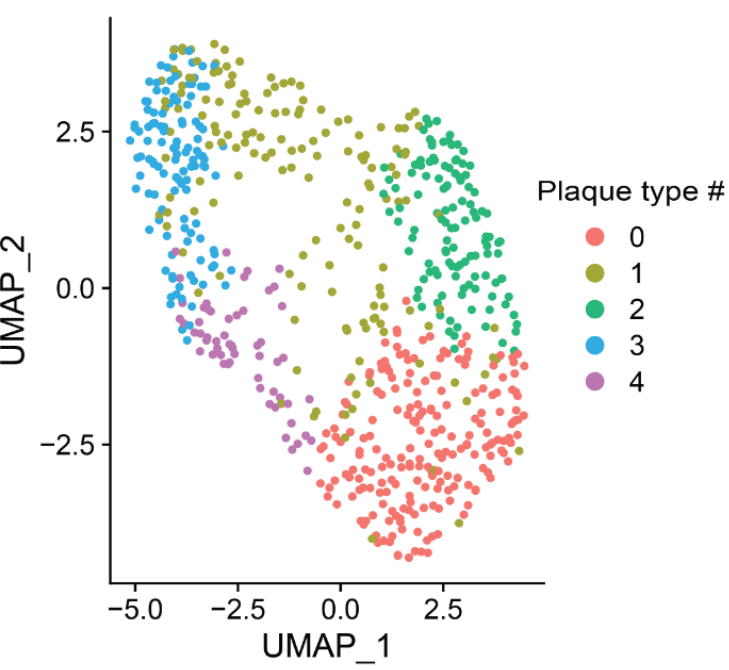

C

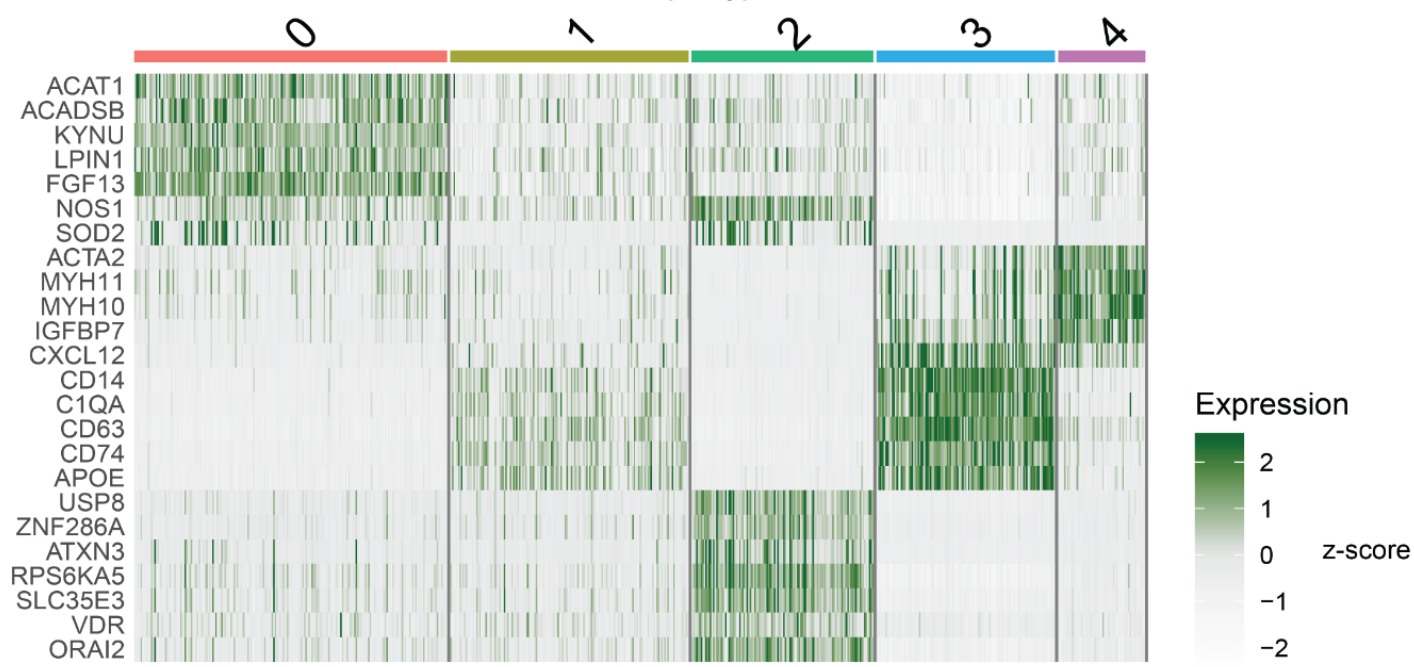

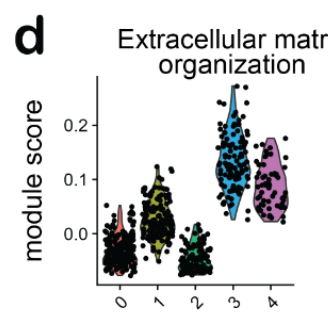

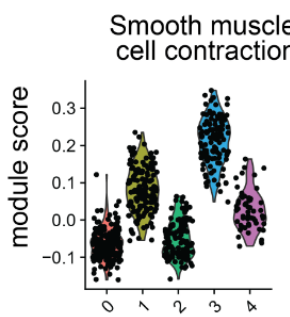

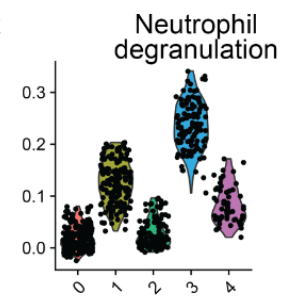

Iron uptake and
transport

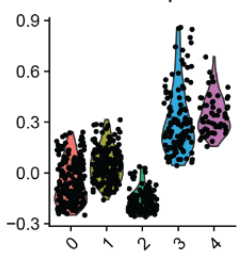

Plaque type \#

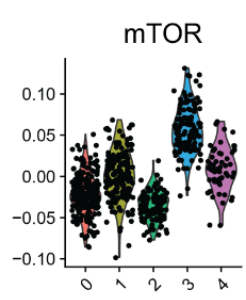

e
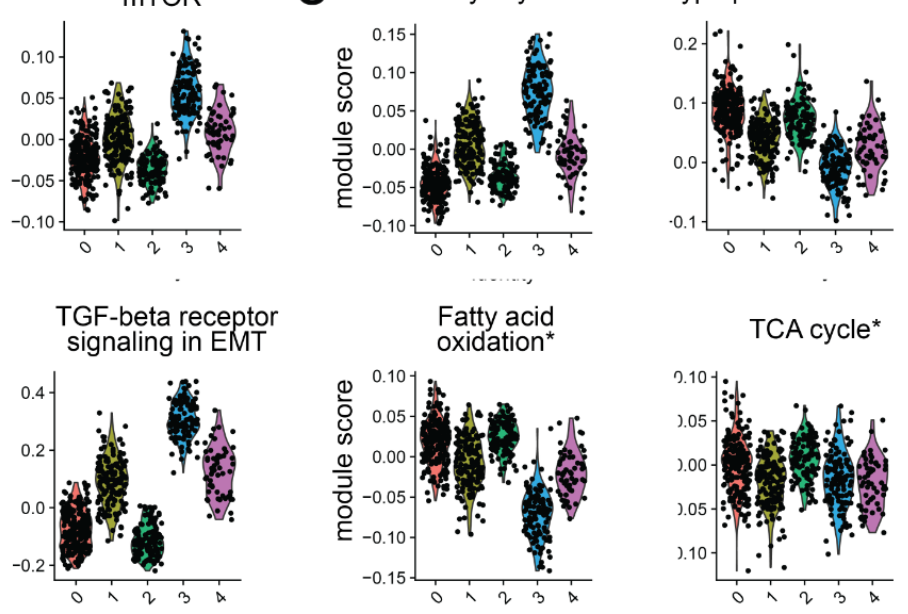

Plaque type \# 
medRxiv preprint doi: https://doi.org/10.1101/2021.11.25.21266855; this version posted November 26, 2021. The copyright holder for this preprint (which was not certified by peer review) is the author/funder, who has granted medRxiv a license to display the preprint in perpetuity. It is made available under a CC-BY-NC-ND 4.0 International license .

Figure 1 Unsupervised clustering of plaques based on transcriptomics data. a) A schematic workflow of the clustering analysis. b) UMAP projection of the 654 plaque samples based on RNA-seq dataset. The color indicates the cluster corresponding to the plaque type from the SNN modularity optimization-based clustering algorithm. c) Heatmap depicts relative gene expression levels of selected plaque type enriched genes in individual samples and plaque clusters. d) Module scores of genes annotated to selected molecular pathways in different plaque clusters. e) Module scores of genes annotated to selected metabolic pathways in different plaque clusters. * depicts empirically selected pathways that were not significantly enriched in the pathway analysis. 
medRxiv preprint doi: https://doi.org/10.1101/2021.11.25.21266855; this version posted November 26, 2021. The copyright holder for this preprint (which was not certified by peer review) is the author/funder, who has granted medRxiv a license to display the preprint in perpetuity.

It is made available under a CC-BY-NC-ND 4.0 International license .
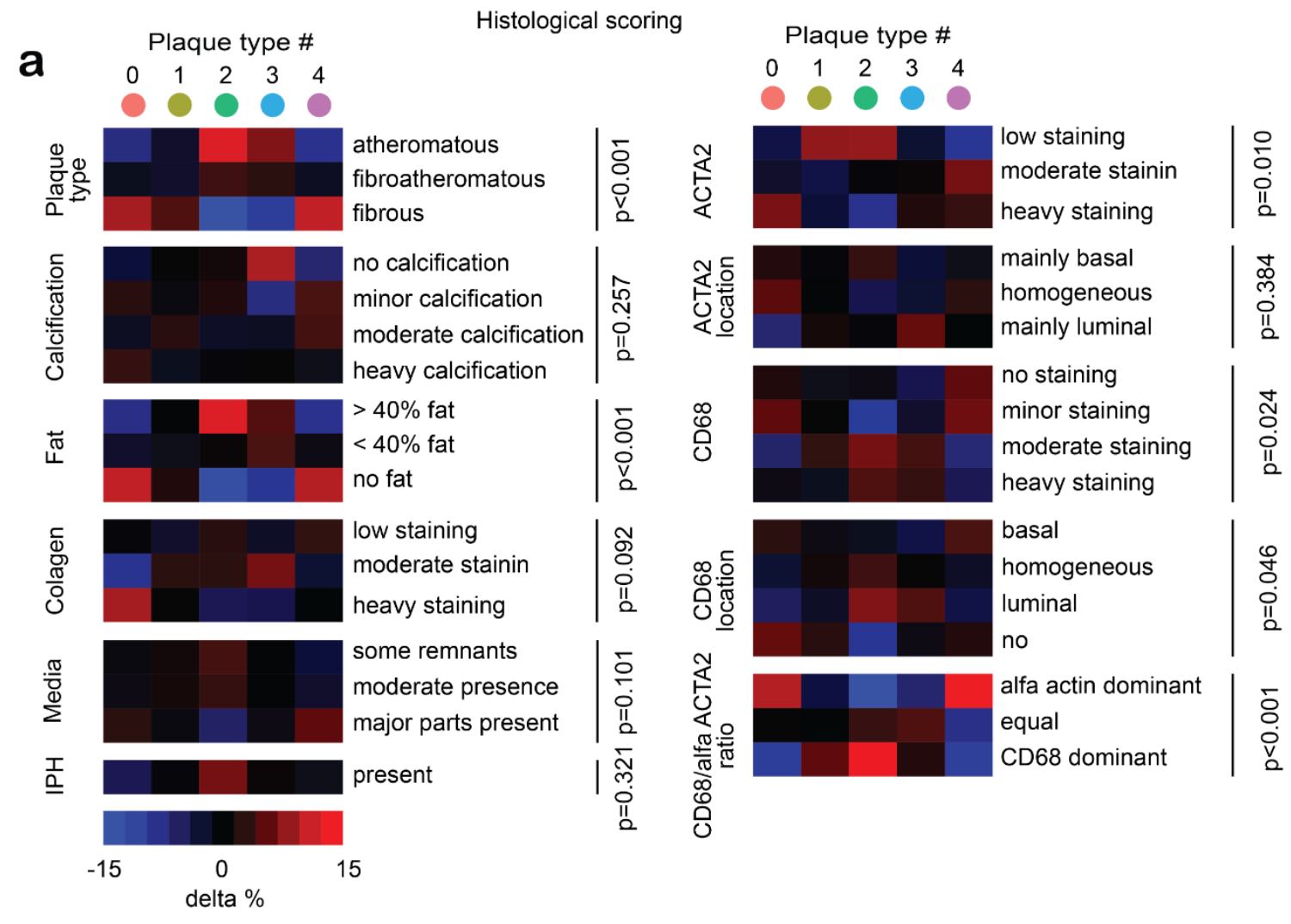

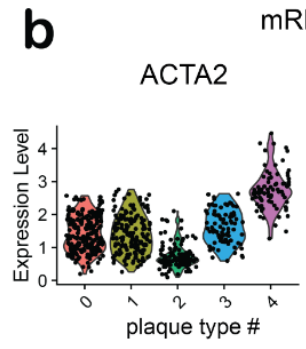

MYH11

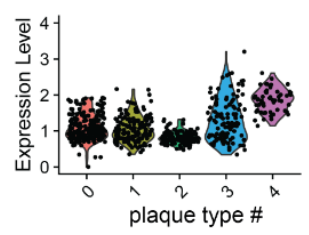

CD3E

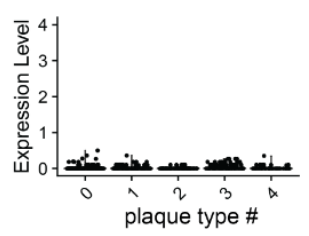

CD8A

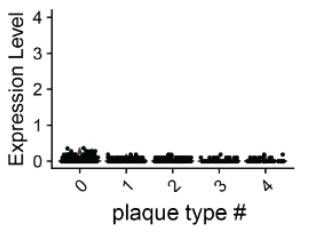

CD14

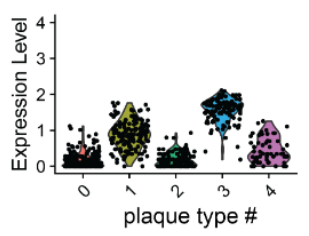

APOE

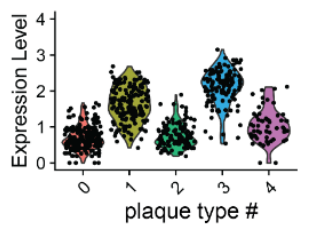

NCAM1

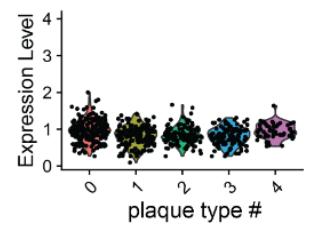

CD19

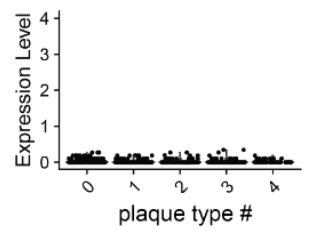

C

Computational deconvolution
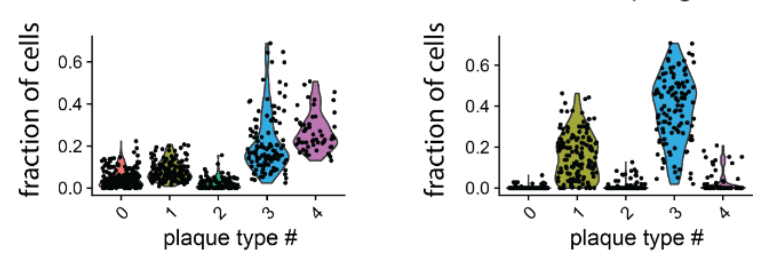

d

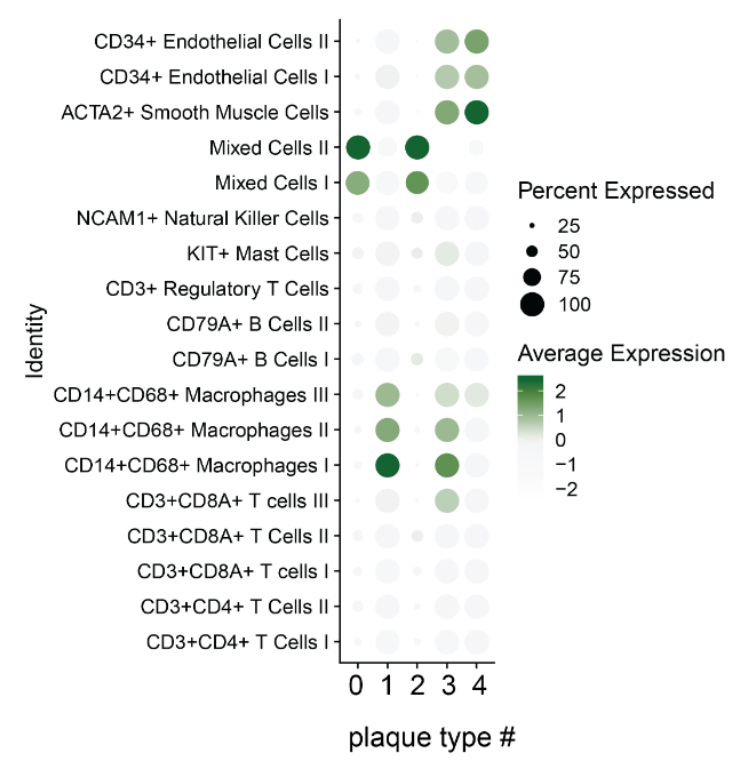


medRxiv preprint doi: https://doi.org/10.1101/2021.11.25.21266855; this version posted November 26, 2021. The copyright holder for this preprint (which was not certified by peer review) is the author/funder, who has granted medRxiv a license to display the preprint in perpetuity.

It is made available under a CC-BY-NC-ND 4.0 International license .

Figure 2 Unsupervised clustering of plaques based and cell composition. a) Distribution of histological features in five transcriptome-based clusters. The percentage represents the difference over equal distribution. (IPH - intraplaque hemorrhage). P-values were calculated using the chi-square test for categorical variables and one-way analysis of variance (ANOVA) for continuous variables. b) Expression of selected cell marker genes in transcriptome-based clusters. c) Fraction of specific cell types contributing to the bulk RNA-seq signal deconvoluted using the reference-based on single-cell transcriptomics dataset. d) Expression of cluster-specific gene sets in single-cell transcriptomics datasets from atherosclerotic plaques.

Genetic assotiation with CAD

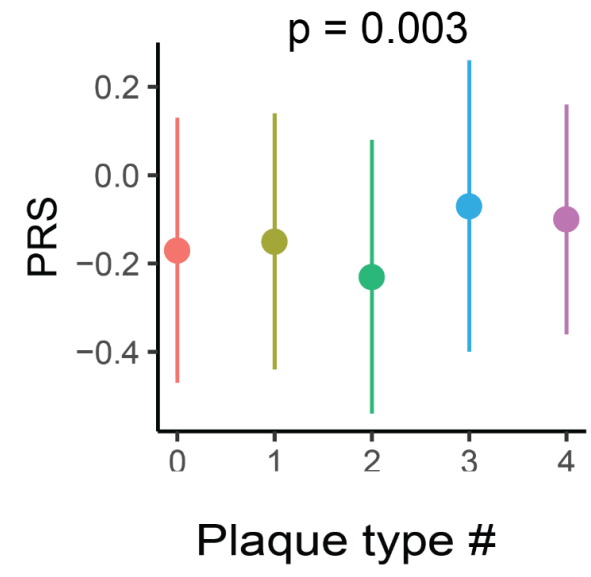

b

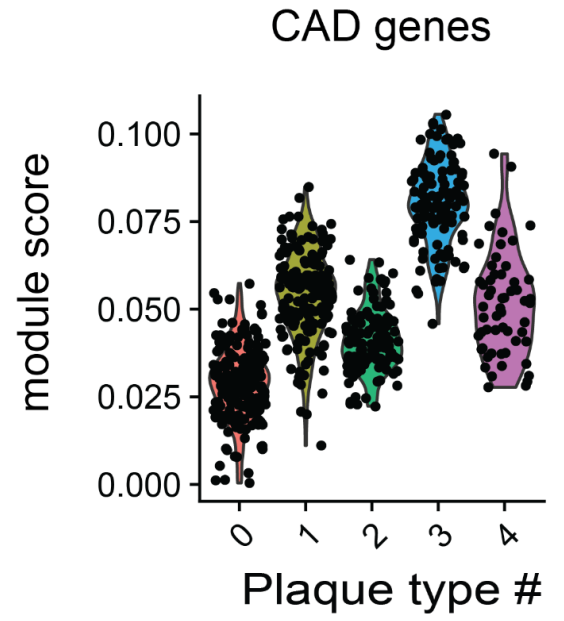


medRxiv preprint doi: https://doi.org/10.1101/2021.11.25.21266855; this version posted November 26, 2021. The copyright holder for this preprint (which was not certified by peer review) is the author/funder, who has granted medRxiv a license to display the preprint in perpetuity.

It is made available under a CC-BY-NC-ND 4.0 International license .

a

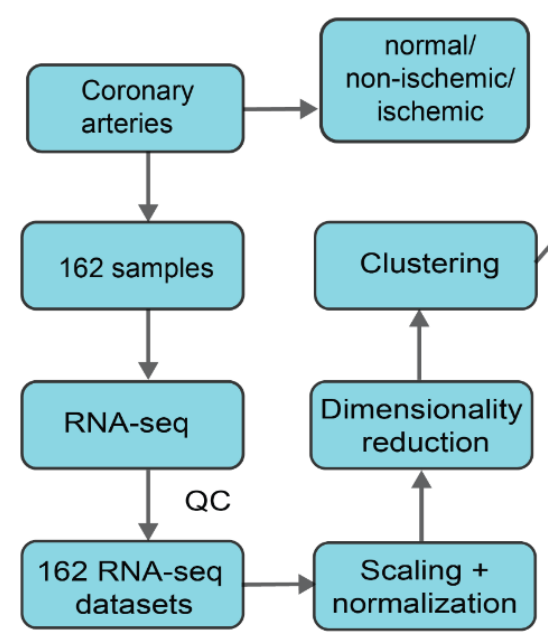

b

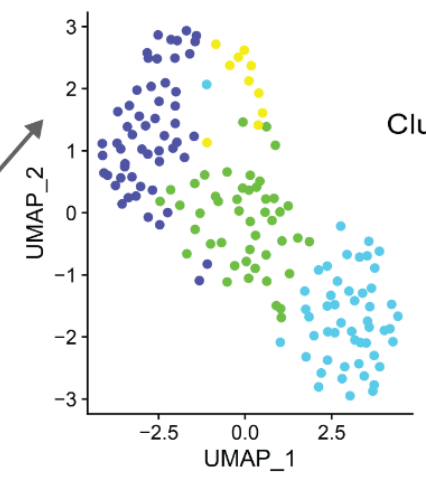

C

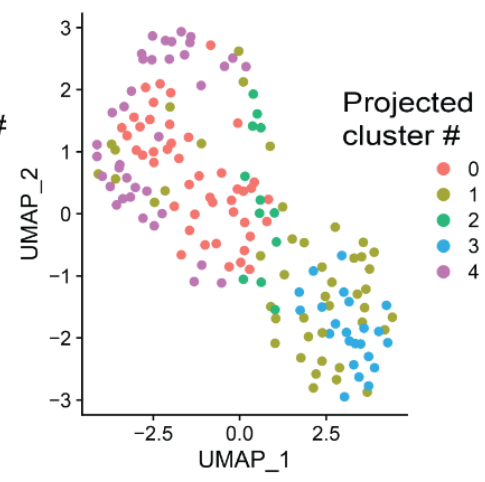

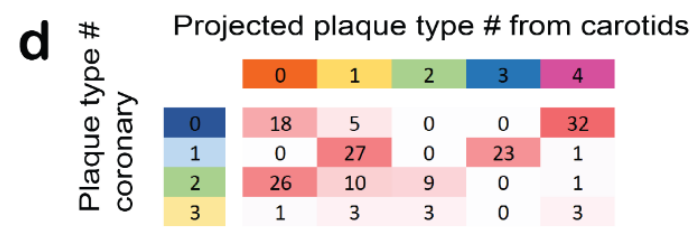
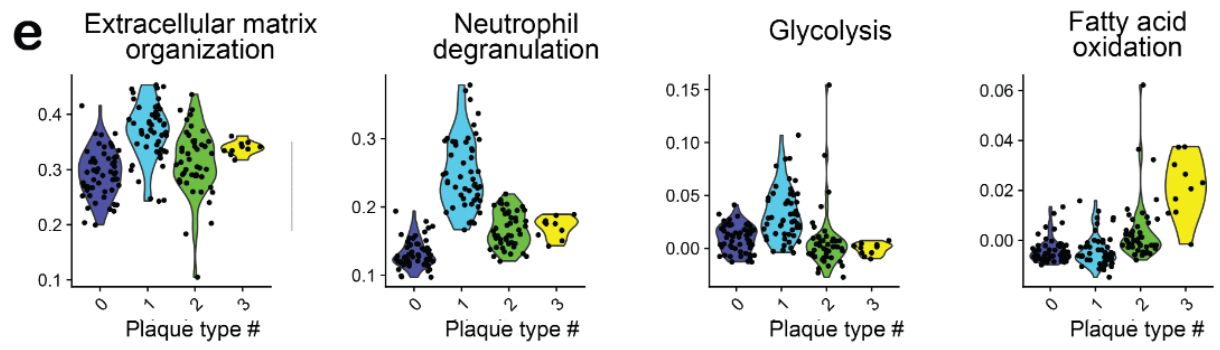

TGF-beta receptor signaling in EMT

\section{f}

\begin{tabular}{l} 
Plaque Type \# \\
\hline $\mathbf{n}$ \\
Classification (\%) \\
Ischemic \\
Nonischemic \\
Normal \\
Other \\
Unknown \\
Age years (mean (SD)
\end{tabular}
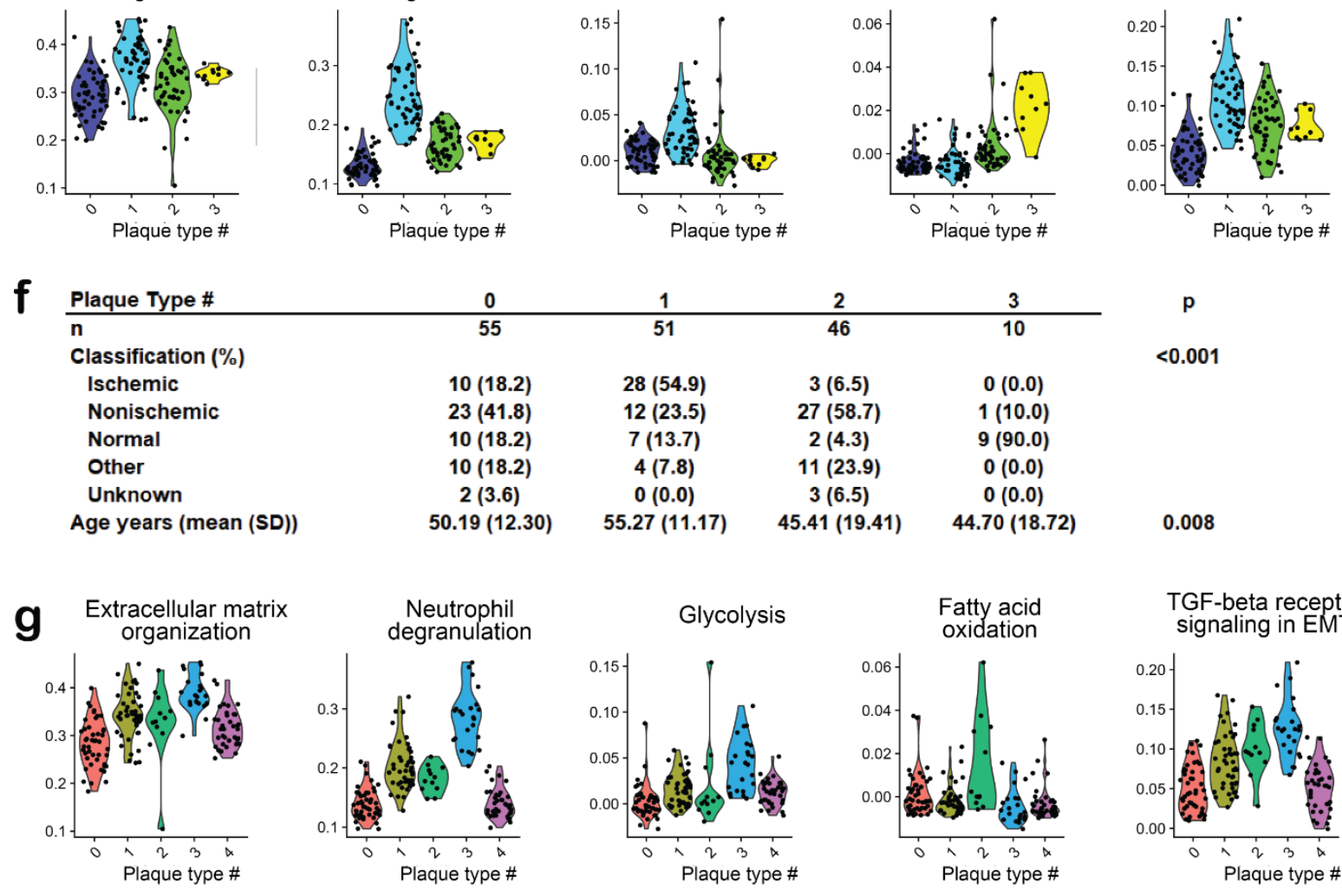

h

\begin{tabular}{l} 
Plaque Type \# \\
\hline $\mathbf{n}$ \\
Classification (\%) \\
Ischemic \\
$\quad$ Nonischemic \\
Normal \\
Other \\
Unknown \\
Age years (mean (SD)
\end{tabular}

$\begin{array}{cc}0 & 1 \\ 45 & 45 \\ 4(8.9) & 19(42.2) \\ 23(51.1) & 20(44.4) \\ 4(8.9) & 3(6.7) \\ 10(22.2) & 3(6.7) \\ 4(8.9) & 0(0.0) \\ 43.78(18.70) & 54.80(12.69)\end{array}$

2
12
$1(8.3)$
$4(33.3)$
$4(33.3)$
$3(25.0)$
$0(0.0)$
$43.75(18.12)$
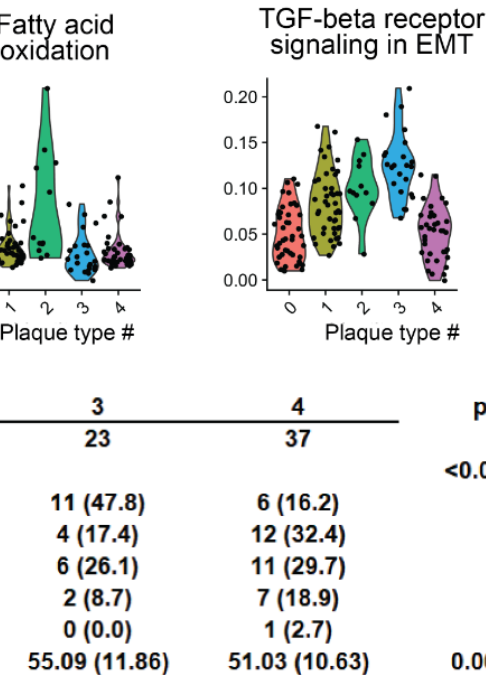
medRxiv preprint doi: https://doi.org/10.1101/2021.11.25.21266855; this version posted November 26, 2021. The copyright holder for this preprint (which was not certified by peer review) is the author/funder, who has granted medRxiv a license to display the preprint in perpetuity.

It is made available under a CC-BY-NC-ND 4.0 International license .

Figure 4 Unsupervised clustering of coronary artery samples based on transcriptomics data. a) A schematic workflow of the clustering analysis. b) UMAP projection of the 162 coronary samples based on RNA-seq dataset. The color indicates the cluster corresponding to the plaque type from the SNN modularity optimization-based clustering algorithm. c) UMAP projection of the 162 coronary samples based on RNA-seq dataset. The color indicates the projected plaque type identity from the carotid dataset. d) Correspondence of clusters derived from coronary data and projected clusters from carotids. Numbers in the table indicate sample counts in the intersection of the corresponding clusters. e) Module scores of genes annotated to selected molecular pathways in individual plaque clusters derived from coronary arteries. f) Distribution of clinical status and age of sample donors in coronary clusters. g) Module scores of genes annotated to selected molecular pathways in individual plaque clusters projected from carotid arteries. h) Distribution of clinical status and age of coronary artery sample donors in projected carotid clusters. 
medRxiv preprint doi: https://doi.org/10.1101/2021.11.25.21266855; this version posted November 26, 2021. The copyright holder for this preprint (which was not certified by peer review) is the author/funder, who has granted medRxiv a license to display the preprint in perpetuity.

It is made available under a CC-BY-NC-ND 4.0 International license .

a

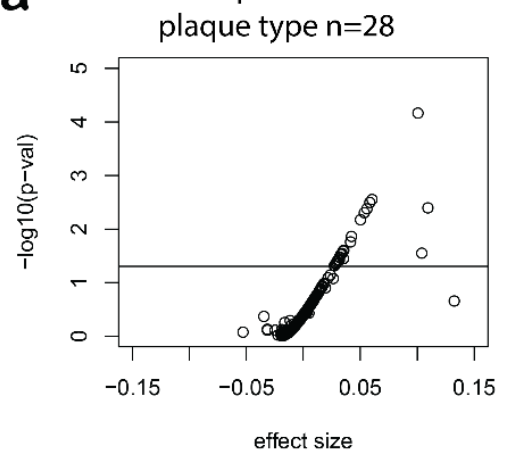

b
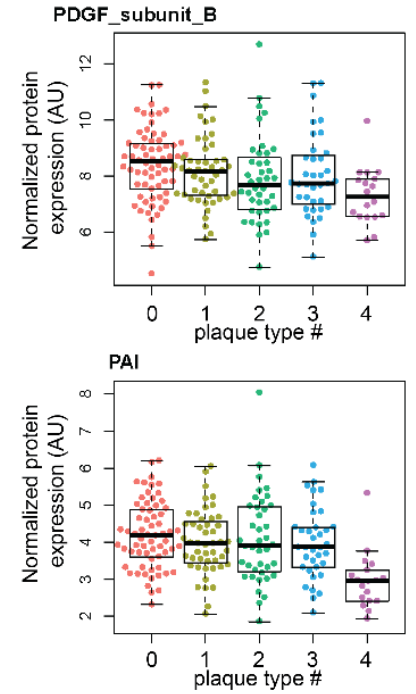

histological phenotype $n=10$

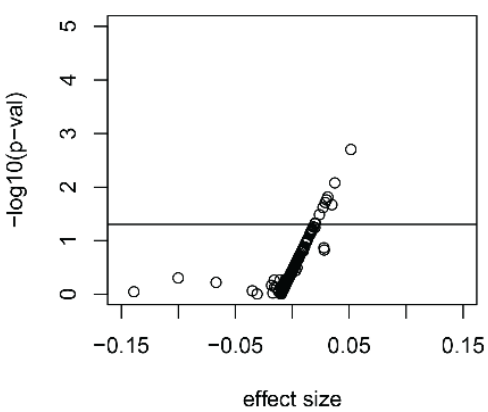

effect size
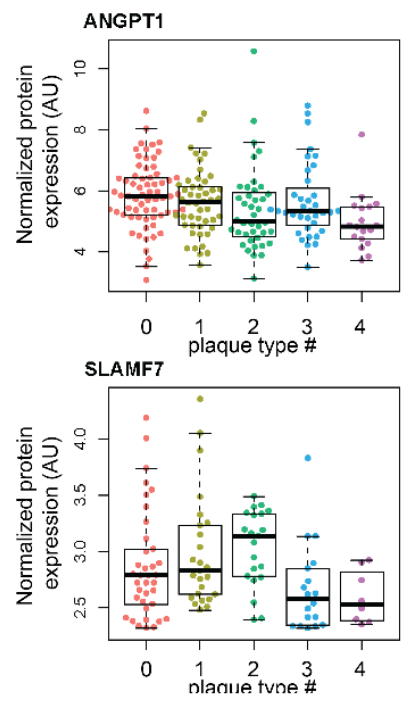

calcification $n=10$
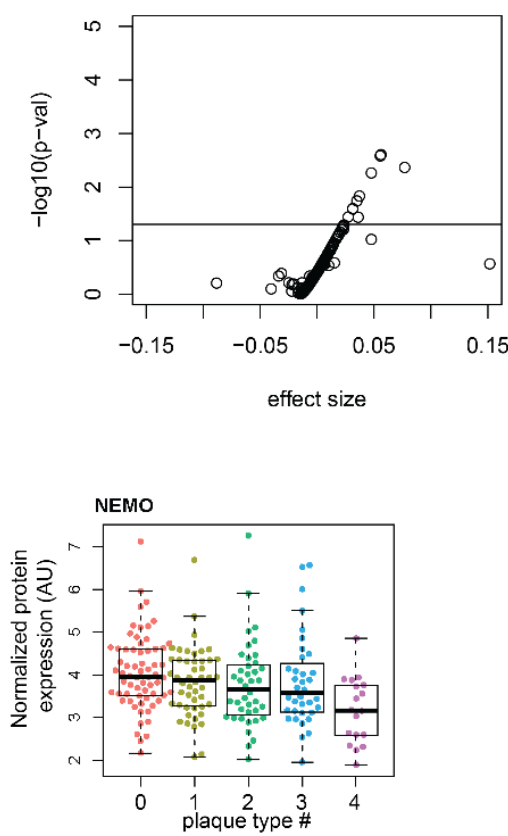
medRxiv preprint doi: https://doi.org/10.1101/2021.11.25.21266855; this version posted November 26, 2021. The copyright holder for this preprint (which was not certified by peer review) is the author/funder, who has granted medRxiv a license to display the preprint in perpetuity.

It is made available under a CC-BY-NC-ND 4.0 International license .

\section{Tables}

\begin{tabular}{|c|c|c|c|c|c|c|}
\hline Plaque type \# & 0 & 1 & 2 & 3 & 4 & $p$ \\
\hline $\mathrm{n}$ & 200 & 147 & 116 & 114 & 55 & \\
\hline sex = male $(\%)$ & $144(72.0)$ & $111(75.5)$ & $92(79.3)$ & $89(78.1)$ & $40(72.7)$ & 0.584 \\
\hline current smoker (\%) & $80(40.0)$ & $46(31.9)$ & $36(31.6)$ & $41(36.3)$ & $23(42.6)$ & 0.356 \\
\hline DM (\%) & $54(27.0)$ & $28(19.0)$ & $20(17.2)$ & $23(20.2)$ & $11(20.0)$ & 0.236 \\
\hline hypertension (\%) & $144(74.2)$ & $106(73.1)$ & $82(71.9)$ & $81(73.0)$ & $34(61.8)$ & 0.486 \\
\hline No history of CAD (\%) & $135(67.5)$ & $86(58.5)$ & $83(71.6)$ & $79(69.3)$ & $38(69.1)$ & 0.184 \\
\hline No history of stroke (\%) & $146(73.0)$ & $102(69.4)$ & $73(62.9)$ & $78(68.4)$ & $42(76.4)$ & 0.308 \\
\hline paod $(\%)$ & $50(25.0)$ & $40(27.2)$ & $21(18.1)$ & $20(17.5)$ & $8(14.5)$ & 0.112 \\
\hline symptoms (\%) & & & & & & 0.001 \\
\hline asymptomatic & $42(21.1)$ & $17(12.0)$ & $9(8.0)$ & $17(15.0)$ & $10(18.5)$ & \\
\hline ocular & $46(23.1)$ & $28(19.7)$ & $13(11.6)$ & $9(8.0)$ & $11(20.4)$ & \\
\hline TIA & $73(36.7)$ & $61(43.0)$ & $53(47.3)$ & $58(51.3)$ & $23(42.6)$ & \\
\hline stroke & $38(19.1)$ & $36(25.4)$ & $37(33.0)$ & $29(25.7)$ & $10(18.5)$ & \\
\hline age years (mean (SD)) & $67.18(8.88)$ & $69.08(8.80)$ & $70.41(9.23)$ & $67.53(8.80)$ & $68.87(8.30)$ & 0.019 \\
\hline bmi (mean (SD)) & $27.19(3.59)$ & $26.37(4.08)$ & $26.57(3.22)$ & $26.34(4.07)$ & $25.83(3.94)$ & 0.095 \\
\hline total chol [mmol/L] (mean (SD)) & $4.59(1.27)$ & $4.48(1.24)$ & $4.11(1.08)$ & $4.58(1.32)$ & $4.44(1.11)$ & 0.05 \\
\hline triglycerides [mmol/L] (mean (SD)) & $1.75(0.95)$ & $1.67(0.83)$ & $1.70(1.01)$ & $1.76(1.17)$ & $1.52(0.82)$ & 0.688 \\
\hline Idl [mmol/L] (mean (SD)) & $2.62(1.01)$ & $2.50(0.90)$ & $2.39(0.92)$ & $2.61(1.10)$ & $2.49(0.91)$ & 0.464 \\
\hline hdl [mmol/L] (mean (SD)) & $1.14(0.38)$ & $1.10(0.33)$ & $1.03(0.32)$ & $1.11(0.28)$ & $1.12(0.39)$ & 0.162 \\
\hline plaquephenotype (\%) & & & & & & $<0.001$ \\
\hline atheromatous & $44(22.2)$ & $40(27.6)$ & $49(43.0)$ & $43(38.1)$ & $11(20.8)$ & \\
\hline fibroatheromatous & $71(35.9)$ & $51(35.2)$ & $48(42.1)$ & $46(40.7)$ & $19(35.8)$ & \\
\hline fibrous & $83(41.9)$ & $54(37.2)$ & $17(14.9)$ & $24(21.2)$ & $23(43.4)$ & \\
\hline
\end{tabular}

\section{Acknowledgements}

The authors would like to thank the Utrecht Sequencing Facility for continuous support and patience. This work was supported by The Dutch Heart Foundation (CVON2017-20: Generating the best evidence-based pharmaceutical targets and drugs for atherosclerosis [GENIUS II] to G. Pasterkamp, S.W. van der Laan); Fondation Leducq (Transatlantic Network Grant PlaqOmics to N. J. Leeper, M. Civelek. G. K. Owens, A. V. Finn, Clint. L. Miller and G. Pasterkamp); EU 755320 Taxinomisis grant (E. Pavlos, E. Andreakos, G.J. de Borst, A. Boltjes, G. Pasterkamp). We acknowledge the European Research Area Network on Cardiovascular Diseases (ERA-CVD, grant number 01KL1802 to F. W. Asselbrgs, S.W. van der Laan, G. Pasterkamp); the ERA-Endless consortium (Dutch Heart Foundation, grant number 2017/T099 to H.M. 
medRxiv preprint doi: https://doi.org/10.1101/2021.11.25.21266855; this version posted November 26, 2021. The copyright holder for this preprint (which was not certified by peer review) is the author/funder, who has granted medRxiv a license to display the preprint in perpetuity.

It is made available under a CC-BY-NC-ND 4.0 International license .

den Ruijter and G. Pasterkamp), European Research Council (ERC) consolidator grant (grant number 866478 UCARE to H.M. den Ruijter). The authors would like to thank the Utrecht Sequencing Facility for continuous support and patience.

\section{Author contributions}

$M M A B$ analyzed and integrated the data. $S W v / d L$ and $J M$ provided PRS calculations. $A B, S W v / d L$, performed patient selection, randomization and sample handling. GJdeB performed carotid endarterectomy procedures. NAMv/dD, NL and EM tested library preparation strategies and processed coronary samples for sequencing. MACD, KHMP, LS, MPJW, JP provided, analyzed and interpreted single cell sequencing data. KC performed deconvolution of bulk RNA-seq data. JM, NT, FW, MCV recruited the patients coordinated by DPVdeK. DPVdeK, ESGS provided and coordinated Olink measurements. LS and SWv/dL performed MAGMA analysis. AB, NT, FW, DPVdeK, HMdenR, FWA, SWv/d Laan participated in conceptualization, data interpretation, and provided critical feedback on the article. EDB, RJGH, EP, EA, HS, GKO, CM, AVF, RV, NJL and MC participated in data interpretation, and provided critical feedback on the article. AWT, MDK, CJH and CLM recruited, processed and analyzed coronary samples. EA, FWA, SWv/dL, CLM, MM, GP provided funding. MM, CLM and GP participated in the conceptualization and supervision of the project and finalization of the article. MM prepared the figures. MM and GP drafted the manuscript. All authors provided feedback on the research, analyses, and article.

\section{Data availability}

The data are not publicly available due to research participant privacy/consent. 


\section{Code availability}

The core scripts used for the analysis can be found at

https://github.com/CirculatoryHealth/PlaqueCluster

\section{References}

1. Falk E. Plaque rupture with severe pre-existing stenosis precipitating coronary thrombosis. Characteristics of coronary atherosclerotic plaques underlying fatal occlusive thrombi. Br Heart J. 1983 Aug;50(2):127-34.

2. Davies MJ, Thomas AC. Plaque fissuring--the cause of acute myocardial infarction, sudden ischaemic death, and crescendo angina. Br Heart J. 1985 Apr;53(4):363-73.

3. Franzén O, Ermel R, Cohain A, Akers NK, Di Narzo A, Talukdar HA, et al. Cardiometabolic risk loci share downstream cis- and trans-gene regulation across tissues and diseases. Science. 2016 Aug 19;353(6301):827-30.

4. Hartman RJG, Owsiany K, Ma L, Koplev S, Hao K, Slenders L, et al. Sex-Stratified Gene Regulatory Networks Reveal Female Key Driver Genes of Atherosclerosis Involved in Smooth Muscle Cell Phenotype Switching. Circulation. 2021 Feb 16;143(7):713-26.

5. Perisic L, Aldi S, Sun Y, Folkersen L, Razuvaev A, Roy J, et al. Gene expression signatures, pathways and networks in carotid atherosclerosis. J Intern Med. 2016 Mar;279(3):293-308.

6. Shakhtshneider EV, Ivanoshchuk D, Fishman V, Ragino Y, Kashtanova E, Polonskaya Y, et al. RNASEQ transcriptome analysis of stable and unstable atherosclerotic plaques. Atherosclerosis. 2020 Dec 1;315:e133.

7. Aure MR, Vitelli V, Jernström S, Kumar S, Krohn M, Due EU, et al. Integrative clustering reveals a novel split in the luminal A subtype of breast cancer with impact on outcome. Breast Cancer Res. 2017 Mar 29;19(1):44.

8. Zhao L, Zhao H, Yan H. Gene expression profiling of 1200 pancreatic ductal adenocarcinoma reveals novel subtypes. BMC Cancer. 2018 May 29;18(1):603.

9. Lapointe J, Li C, Higgins JP, van de Rijn M, Bair E, Montgomery K, et al. Gene expression profiling identifies clinically relevant subtypes of prostate cancer. Proc Natl Acad Sci U S A. 2004 Jan 20;101(3):811-6.

10. Bertucci F, Finetti P, Rougemont J, Charafe-Jauffret E, Cervera N, Tarpin C, et al. Gene expression 
profiling identifies molecular subtypes of inflammatory breast cancer. Cancer Res. 2005 Mar 15;65(6):2170-8.

11. Wang X, Park J, Susztak K, Zhang NR, Li M. Bulk tissue cell type deconvolution with multi-subject single-cell expression reference. Nat Commun. 2019 Jan 22;10(1):380.

12. Depuydt MAC, Prange KHM, Slenders L, Örd T, Elbersen D, Boltjes A, et al. Microanatomy of the Human Atherosclerotic Plaque by Single-Cell Transcriptomics. Circ Res. 2020 Nov 6;127(11):143755.

13. Costales P, Fuentes-Prior P, Castellano J, Revuelta-Lopez E, Corral-Rodríguez MÁ, Nasarre L, et al. K Domain CR9 of Low Density Lipoprotein (LDL) Receptor-related Protein 1 (LRP1) Is Critical for Aggregated LDL-induced Foam Cell Formation from Human Vascular Smooth Muscle Cells. J Biol Chem. 2015 Jun 12;290(24):14852-65.

14. Erdmann J, Kessler T, Munoz Venegas L, Schunkert H. A decade of genome-wide association studies for coronary artery disease: the challenges ahead. Cardiovasc Res. 2018 Jul 15;114(9):1241-57.

15. Timmerman N, de Kleijn DPV, de Borst GJ, den Ruijter HM, Asselbergs FW, Pasterkamp G, et al. Family history and polygenic risk of cardiovascular disease: Independent factors associated with secondary cardiovascular events in patients undergoing carotid endarterectomy. Atherosclerosis. 2020 Aug;307:121-9.

16. de Leeuw CA, Mooij JM, Heskes T, Posthuma D. MAGMA: generalized gene-set analysis of GWAS data. PLoS Comput Biol. 2015 Apr;11(4):e1004219.

17. Hartiala JA, Han Y, Jia Q, Hilser JR, Huang P, Gukasyan J, et al. Genome-wide analysis identifies novel susceptibility loci for myocardial infarction. Eur Heart J. 2021 Mar 1;42(9):919-33.

18. Stuart T, Butler A, Hoffman P, Hafemeister C, Papalexi E, Mauck WM 3rd, et al. Comprehensive Integration of Single-Cell Data. Cell. 2019 Jun 13;177(7):1888-902.e21.

19. Newman AAC, Serbulea V, Baylis RA, Shankman LS, Bradley X, Alencar GF, et al. Multiple cell types contribute to the atherosclerotic lesion fibrous cap by PDGFR $\beta$ and bioenergetic mechanisms. Nat Metab. 2021 Feb;3(2):166-81.

20. Xia Z, Gu M, Jia X, Wang X, Wu C, Guo J, et al. Integrated DNA methylation and gene expression analysis identifies SLAMF7 as a key regulator of atherosclerosis. Aging . 2018 Jun 13;10(6):1324-37.

21. Gisterå A, Hansson GK. The immunology of atherosclerosis. Nat Rev Nephrol. 2017 Jun;13(6):36880.

22. Libby P, Hansson GK. From Focal Lipid Storage to Systemic Inflammation: JACC Review Topic of the Week. J Am Coll Cardiol. 2019 Sep 24;74(12):1594-607.

23. Farb A, Burke AP, Tang AL, Liang TY, Mannan P, Smialek J, et al. Coronary plaque erosion without rupture into a lipid core. A frequent cause of coronary thrombosis in sudden coronary death. Circulation. 1996 Apr 1;93(7):1354-63.

24. Arbustini E, Dal Bello B, Morbini P, Burke AP, Bocciarelli M, Specchia G, et al. Plaque erosion is a 
medRxiv preprint doi: https://doi.org/10.1101/2021.11.25.21266855; this version posted November 26, 2021. The copyright holder for this preprint (which was not certified by peer review) is the author/funder, who has granted medRxiv a license to display the preprint in perpetuity.

It is made available under a CC-BY-NC-ND 4.0 International license.

major substrate for coronary thrombosis in acute myocardial infarction. Heart. 1999 Sep;82(3):26972.

25. Libby P, Pasterkamp G, Crea F, Jang I-K. Reassessing the Mechanisms of Acute Coronary Syndromes. Circ Res. 2019 Jan 4;124(1):150-60.

26. Libby P, Pasterkamp G. Requiem for the "vulnerable plaque." Eur Heart J. 2015 Nov 14;36(43):2984-7.

27. Nikpay M, Goel A, Won H-H, Hall LM, Willenborg C, Kanoni S, et al. A comprehensive 1,000 Genomes-based genome-wide association meta-analysis of coronary artery disease. Nat Genet. 2015 Oct;47(10):1121-30.

28. Yahagi K, Kolodgie FD, Lutter C, Mori H, Romero ME, Finn AV, et al. Pathology of Human Coronary and Carotid Artery Atherosclerosis and Vascular Calcification in Diabetes Mellitus. Arterioscler Thromb Vasc Biol. 2017 Feb;37(2):191-204.

29. Stone GW, Maehara A, Lansky AJ, de Bruyne B, Cristea E, Mintz GS, et al. A prospective naturalhistory study of coronary atherosclerosis. N Engl J Med. 2011 Jan 20;364(3):226-35.

30. Stone GW, Maehara A, Ali ZA, Held C, Matsumura M, Kjøller-Hansen L, et al. Percutaneous Coronary Intervention for Vulnerable Coronary Atherosclerotic Plaque. J Am Coll Cardiol. 2020 Nov 17;76(20):2289-301.

31. Fernandez DM, Rahman AH, Fernandez NF, Chudnovskiy A, Amir E-AD, Amadori L, et al. Single-cell immune landscape of human atherosclerotic plaques. Nat Med. 2019 Oct;25(10):1576-88.

32. Winkels H, Ehinger E, Vassallo M, Buscher K, Dinh HQ, Kobiyama K, et al. Atlas of the Immune Cell Repertoire in Mouse Atherosclerosis Defined by Single-Cell RNA-Sequencing and Mass Cytometry. Circ Res. 2018 Jun 8;122(12):1675-88.

33. Josefs T, Barrett TJ, Brown EJ, Quezada A, Wu X, Voisin M, et al. Neutrophil extracellular traps promote macrophage inflammation and impair atherosclerosis resolution in diabetic mice. JCI Insight [Internet]. 2020 Apr 9;5(7). Available from: http://dx.doi.org/10.1172/jci.insight.134796

34. Schumski A, Ortega-Gómez A, Wichapong K, Winter C, Lemnitzer $P$, Viola JR, et al. Endotoxinemia Accelerates Atherosclerosis Through Electrostatic Charge-Mediated Monocyte Adhesion. Circulation. 2021 Jan 19;143(3):254-66.

35. Döring Y, Libby P, Soehnlein O. Neutrophil Extracellular Traps Participate in Cardiovascular Diseases: Recent Experimental and Clinical Insights. Circ Res. 2020 Apr 24;126(9):1228-41.

36. Silvestre-Roig C, Braster Q, Wichapong K, Lee EY, Teulon JM, Berrebeh N, et al. Externalized histone $\mathrm{H} 4$ orchestrates chronic inflammation by inducing lytic cell death. Nature. 2019 May;569(7755):236-40.

37. Gomez I, Ward B, Souilhol C, Recarti C, Ariaans M, Johnston J, et al. Neutrophil microvesicles drive atherosclerosis by delivering miR-155 to atheroprone endothelium. Nat Commun. 2020 Jan 10;11(1):214. 
38. Tomas L, Edsfeldt A, Mollet IG, Perisic Matic L, Prehn C, Adamski J, et al. Altered metabolism distinguishes high-risk from stable carotid atherosclerotic plaques. Eur Heart J. 2018 Jun 21;39(24):2301-10.

39. Shi J, Yang Y, Cheng A, Xu G, He F. Metabolism of vascular smooth muscle cells in vascular diseases. Am J Physiol Heart Circ Physiol. 2020 Sep 1;319(3):H613-31.

40. De Bock K, Georgiadou M, Schoors S, Kuchnio A, Wong BW, Cantelmo AR, et al. Role of PFKFB3driven glycolysis in vessel sprouting. Cell. 2013 Aug 1;154(3):651-63.

41. Kang H, Kim H, Lee S, Youn H, Youn B. Role of Metabolic Reprogramming in Epithelial-Mesenchymal Transition (EMT). Int J Mol Sci [Internet]. 2019 Apr 25;20(8). Available from: http://dx.doi.org/10.3390/ijms20082042

42. Cornelissen A, Guo L, Sakamoto A, Virmani R, Finn AV. New insights into the role of iron in inflammation and atherosclerosis. EBioMedicine. 2019 Sep;47:598-606.

43. Sakamoto A, Guo L, Paek KH, Fernandez R, Cornelissen A, Jinnouchi H, et al. Abstract 13413: CD163+ Alternative Macrophage Inhibits Atherosclerotic Calcification via Enhancement of Hyaluronan Production in Vascular Smooth Muscle Cells. Circulation. 2019 Nov 19;140(Suppl_1):A13413-A13413.

44. Mega JL, Stitziel NO, Smith JG, Chasman DI, Caulfield M, Devlin JJ, et al. Genetic risk, coronary heart disease events, and the clinical benefit of statin therapy: an analysis of primary and secondary prevention trials. Lancet. 2015 Jun 6;385(9984):2264-71.

45. Fateh-Moghadam S, Li Z, Ersel S, Reuter T, Htun P, Plöckinger U, et al. Platelet degranulation is associated with progression of intima-media thickness of the common carotid artery in patients with diabetes mellitus type 2. Arterioscler Thromb Vasc Biol. 2005 Jun;25(6):1299-303.

46. Li X, He X, Wang J, Wang D, Cong P, Zhu A, et al. The Regulation of Exosome-Derived miRNA on Heterogeneity of Macrophages in Atherosclerotic Plaques. Front Immunol. 2020 Sep 10;11:2175.

47. Bhatia VK, Yun S, Leung V, Grimsditch DC, Benson GM, Botto MB, et al. Complement C1q reduces early atherosclerosis in low-density lipoprotein receptor-deficient mice. Am J Pathol. 2007 Jan;170(1):416-26.

48. Tomaniak M, Katagiri Y, Modolo R, de Silva R, Khamis RY, Bourantas CV, et al. Vulnerable plaques and patients: state-of-the-art. Eur Heart J. 2020 Aug 14;41(31):2997-3004.

49. Lind L, Gigante B, Borné Y, Feldreich T, Leppert J, Hedberg P, et al. Plasma Protein Profile of Carotid Artery Atherosclerosis and Atherosclerotic Outcomes. Arterioscler Thromb Vasc Biol. 2021 May 5;41(5):1777-88.

50. Verhoeven BAN, Velema E, Schoneveld AH, de Vries JPPM, de Bruin P, Seldenrijk CA, et al. Atheroexpress: differential atherosclerotic plaque expression of mRNA and protein in relation to cardiovascular events and patient characteristics. Rationale and design. Eur J Epidemiol. 2004;19(12):1127-33.

51. Hellings WE, Moll FL, De Vries J-PPM, Ackerstaff RGA, Seldenrijk KA, Met R, et al. Atherosclerotic 
plaque composition and occurrence of restenosis after carotid endarterectomy. JAMA. 2008 Feb 6;299(5):547-54.

52. Hellings WE, Peeters W, Moll FL, Piers SRD, van Setten J, Van der Spek PJ, et al. Composition of carotid atherosclerotic plaque is associated with cardiovascular outcome: a prognostic study. Circulation. 2010 May 4;121(17):1941-50.

53. van Lammeren GW, den Ruijter HM, Vrijenhoek JEP, van der Laan SW, Velema E, de Vries J-PPM, et al. Time-dependent changes in atherosclerotic plaque composition in patients undergoing carotid surgery. Circulation. 2014 Jun 3;129(22):2269-76.

54. Hashimshony T, Senderovich N, Avital G, Klochendler A, de Leeuw Y, Anavy L, et al. CEL-Seq2: sensitive highly-multiplexed single-cell RNA-Seq. Genome Biol. 2016 Apr 28;17:77.

55. Waltman L, van Eck NJ. A smart local moving algorithm for large-scale modularity-based community detection. Eur Phys J B. 2013 Nov 13;86(11):471.

56. Yu G, He Q-Y. ReactomePA: an R/Bioconductor package for reactome pathway analysis and visualization. Mol Biosyst. 2016 Feb;12(2):477-9.

57. Gullberg M, Gústafsdóttir SM, Schallmeiner E, Jarvius J, Bjarnegård M, Betsholtz C, et al. Cytokine detection by antibody-based proximity ligation. Proc Natl Acad Sci U S A. 2004 Jun 1;101(22):84204.

58. van der Laan SW, Siemelink MA, Haitjema S, Foroughi Asl H, Perisic L, Mokry M, et al. Genetic Susceptibility Loci for Cardiovascular Disease and Their Impact on Atherosclerotic Plaques. Circ Genom Precis Med. 2018 Sep;11(9):e002115.

59. Laurie CC, Doheny KF, Mirel DB, Pugh EW, Bierut L, Bhangale T, et al. Quality control and quality assurance in genotypic data for genome-wide association studies. Genet Epidemiol. 2010 Sep;34(6):591-602.

60. Delaneau O, Marchini J, Zagury J-F. A linear complexity phasing method for thousands of genomes. Nat Methods. 2011 Dec 4;9(2):179-81.

61. Inouye M, Abraham G, Nelson CP, Wood AM, Sweeting MJ, Dudbridge F, et al. Genomic Risk Prediction of Coronary Artery Disease in 480,000 Adults: Implications for Primary Prevention. J Am Coll Cardiol. 2018 Oct 16;72(16):1883-93.

62. Choi SW, O'Reilly PF. PRSice-2: Polygenic Risk Score software for biobank-scale data. Gigascience [Internet]. 2019 Jul 1;8(7). Available from: http://dx.doi.org/10.1093/gigascience/giz082 